This document was prepared in conjunction with work accomplished under Contract No. DE-AC09-96SR18500 with the U.S. Department of Energy.

This work was prepared under an agreement with and funded by the U.S. Government. Neither the U. S. Government or its employees, nor any of its contractors, subcontractors or their employees, makes any express or implied: 1 . warranty or assumes any legal liability for the accuracy, completeness, or for the use or results of such use of any information, product, or process disclosed; or 2 . representation that such use or results of such use would not infringe privately owned rights; or 3 . endorsement or recommendation of any specifically identified commercial product, process, or service. Any views and opinions of authors expressed in this work do not necessarily state or reflect those of the United States Government, or its contractors, or subcontractors. 
WSRC-STI-2006-00158

Rev. 1

\title{
Optimization Study for Fill Stem Manufacturing and Pinch Weld Processing
}

\author{
P. S. Korinko (SRNL) \\ K. F. Arnold (KCP)
}

September 2006

\begin{tabular}{ll}
\hline SRNL & SAVANNAH RIVER NATIONAL LABORATORY, AIKEN, SC 29808 \\
& Westinghouse Savannah River Company \\
& Prepared for the U.S. Department of Energy under Contract DE-AC09-96SR1850
\end{tabular} 
MST

MATERIALS SCIENCE and TECHNOLOGY

$\begin{array}{ll}\text { Keywords: } & \text { Stainless steel } \\ & \begin{array}{l}\text { Fill Stems } \\ \text { Pinch welds }\end{array} \\ & \text { Permanent }\end{array}$

\title{
Optimization Study for Fill Stem Manufacturing and Pinch Weld Processing
}

\author{
P.S. Korinko* \\ K. F. Arnold ${ }^{+}$ \\ *Savannah River National Laboratories \\ Materials Compatibility and Welding Technology Group \\ ${ }^{+}$Kansas City Plant operated by \\ Honeywell Federal Manufacturing and Technologies \\ For the NNSA
}

ISSUED: $\quad$ August 2006

SRNL SAVANNAH RIVER NATIONAL LABORATORY, AIKEN, SC 29808

Westinghouse Savannah River Company

Prepared for the U.S. Department of Energy under Contract DE-AC09-96SR18500 
Rev. 1 Manufacturing and Pinch Weld Processing

Document: WSRC-STI-2006-00158 Rev. 1

\section{Title: Optimization Study for Fill Stem Manufacturing and Pinch Weld Processing}

APPROVALS

9-6-2006

P.S. Korinko, Author

Date

Materials Compatibility and Welding Technology

K. F. Arnold, Author

Gas Transfer Systems, KCP

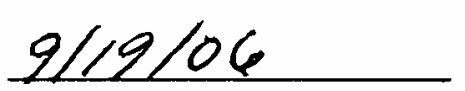

Date

9) 20106

Date

W.L. West, Technical Reviewer

Reservoir Systems Engineering

M.E. Düpont, Acting Manager

- $\frac{9 / 1106}{\text { Date }}$

Materials Compatibility and Welding Technology 


\section{Table of Contents}

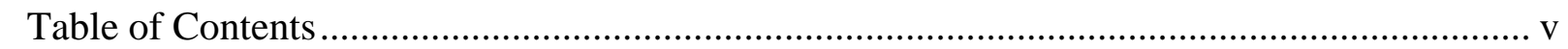

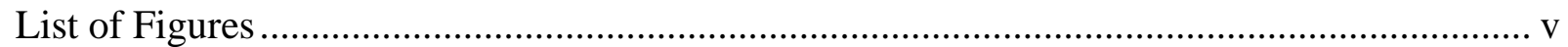

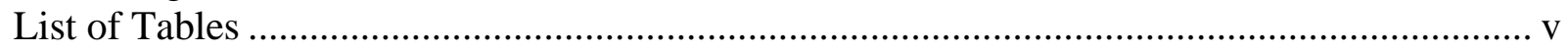

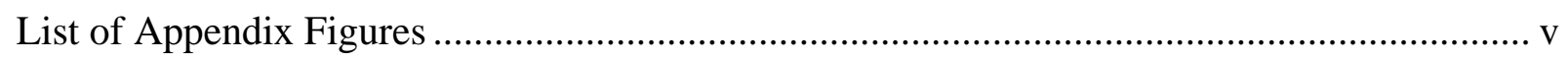

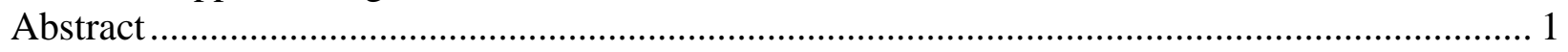

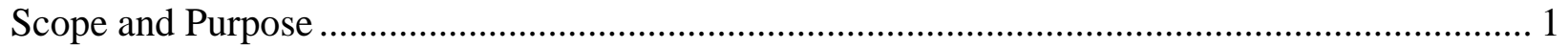

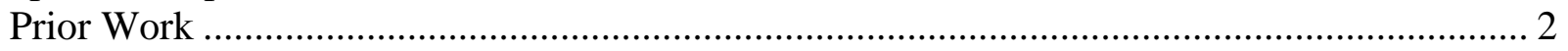

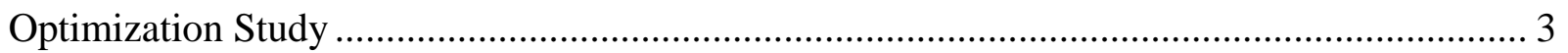

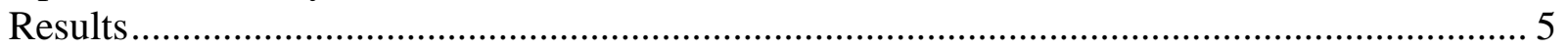

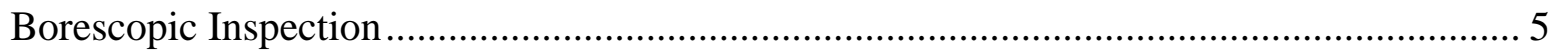

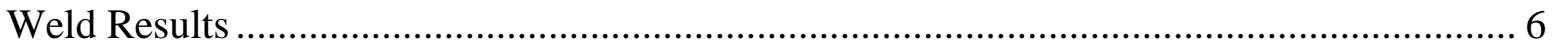

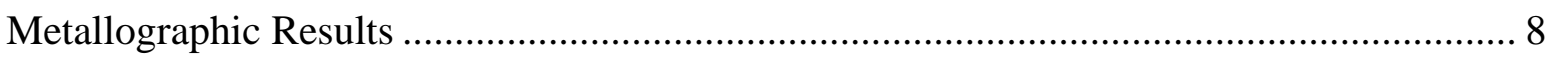

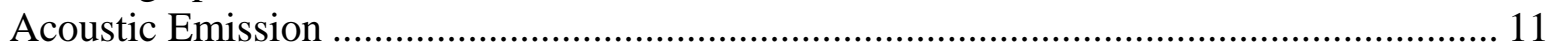

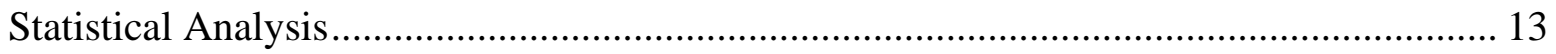

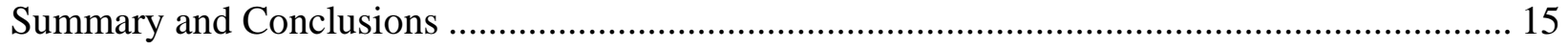

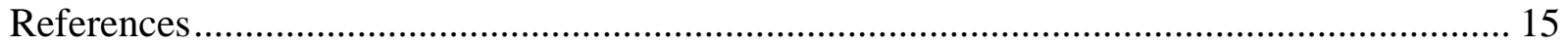

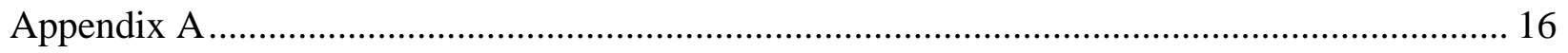

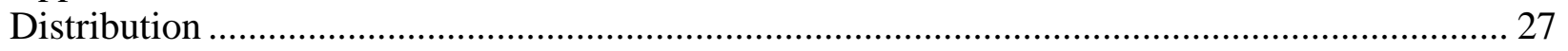

\section{List of Figures}

Figure 1. Fill stem based on a modified LF-7 used for the optimization study (PN PRJ706566-

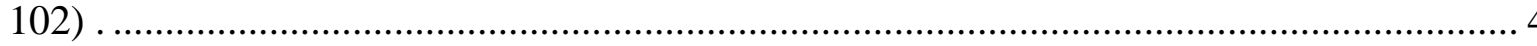

Figure 2. Internal surface of fill stems (a) X0084 and (b) X0079 stems machined with coated drills that were used to drill 4 and 5 holes, respectively.............................................. 6

Figure 3. Weld quality metrics as a function of current .................................................... 8

Figure 4. Destructive weld quality metrics bond rating and burst strength.............................. 9

Figure 5. Micrographs at multiple magnifications showing the structures of the welds for samples produced at (a) 12 cycles / 3500 A / 1258 lbs, X0092 (b) 12 cycles / 3711 A / 1255 lbs, X0094 (c) 12 cycles / 3909 / 1255 lbs, X0087....................................................... 11

Figure 6. Acoustic Emission (AE) data collected (a) during the weld (on heating) and (b) for a period of six seconds (on heating, cooling, and relaxation)......................................... 12

Figure 7. Contour Plot of Pinch Weld Bond Rating Vs. Optimization Parameters Cycles and Current.

\section{List of Tables}

Table 1. Machining and welding parameters used for this study. ........................................... 5

Table 2. Dimensional Requirements for Acceptable Confined Pinch Welds.............................. 5

Table 3. Weld parameters and results for the stems welded for the optimization study. ............. 7

\section{List of Appendix Figures}

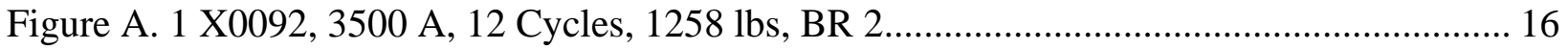

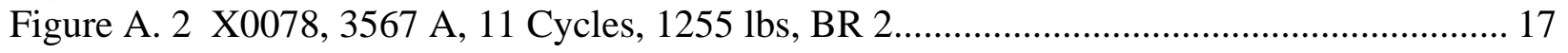


Figure A. 3 X0084, 3574 A, 13 Cycles, 1256 lbs, BR 2 ........................................................... 18

Figure A. 4 X0086, 3701 A, 11 Cycles, 1252 lbs, BR 2 .......................................................... 19

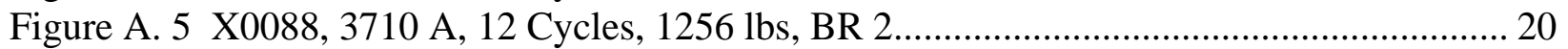

Figure A. 6 X0080, 3711 A, 12 Cycles, 1255 lbs, BR 2..................................................... 21

Figure A. 7 X0094, 3711 A, 12 Cycles, 1255 lbs, BR 2 …....................................................... 22

Figure A. 8 X0093, 3718 A, 13 Cycles, 1257 lbs, BR 2 …….................................................. 23

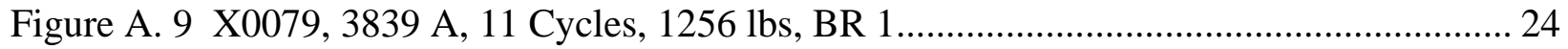

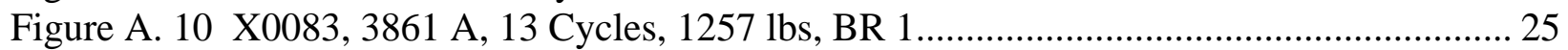

Figure A. 11 X0087, 3909 A, 12 Cycles, 1256 lbs, BR 1.................................................... 26 


\section{Optimization Study for Fill Stem Manufacturing and Pinch Weld Processing}

\section{Abstract}

A statistically designed experiment was conducted as part of a six sigma project for Fill Stem Manufacturing and Pinch Weld Processing. This multi-year / multi-site project has successfully completed a screening study and used those results as inputs to this optimization study. Eleven welds were made using fairly tight current and cycle range. The welds demonstrate increased burst strength, longer closure length, more net displacement, and improved bond rating with increased current. However, excessive melting remains a concern from a processing viewpoint and may cause adverse metallurgical interactions. Therefore, the highest current levels specified cannot be utilized. A Validation Study is proposed for the Defense Programs Inert Facility.

\section{Scope and Purpose}

This report covers the activities of the NNSA Nuclear Weapons Complex (NWC) stem processing team that is using a systematic designed experiment approach to optimization and control of Fill Stem Manufacturing and Pinch Weld Processing. This team is composed of the members of the gas transfer system community from all involved production and design agencies. Representatives from LANL, SNL/CA, SRS, SRNL and the KCP were actively involved in all phases of this project. The team goal is to identify and control process variables important to pinch weld quality and to ensure War Reserve (WR) acceptable pinch welds in production. A screening study was completed and reported in Ref. 1. This report details the progress of the Optimization Testing for the study. Fill stems were manufactured using the Nagel twin spindle drill at the KCP and pinch welded on the development welder in SRNL. The same series of evaluations, i.e., dimensional, radiographic, and metallurgical, were used for this study as for the screening study including experimental evaluation techniques such as ultrasonic inspection and acoustic emission analysis.

The scope and outcome of this project are significant and have been useful in developing understanding of the manufacturing and pinch weld processes and processing interactions. The stem processing team has representatives from each Nuclear Weapons Complex (NWC) sites that have a stake in producing acceptable gas transfer systems. Results of this activity will help to implement the most robust and well characterized fill stem manufacturing and pinch welding process in several decades. Every weapons program and system will benefit from the cooperative effort between the design laboratories and the production agencies participating in this project. The results of this project are the beginning of a systematic approach to understanding the effects of manufacturing variables on product function. Designed experiments have been used to map out critical issues relative to pinch welding. This approach systematically identifies which manufacturing parameters and confirms which welding parameters are critical to pinch welding. This data can be used to prioritize our activities so that we focus on the factors that affect the final product, a safe, reliable closure welded reservoir. 


\section{Prior Work}

The Fill Stem Manufacturing and Pinch Weld Processing work was preceded by the activities of the Pinch Weld Quality team which was composed of members from SNL/CA, SRS, and KCP. This team focused on issues specific to the SP800 (SP981forging) and a dark and light surface morphology defined as "smeared metal" that was observed in stem bores of that product. The Pinch Weld Quality Team concluded the gun drilling process created a work hardened layer on the interior surface of the Regal oil gun drilled and acid cleaned stems that somehow interfered with the pinch weld. The team also decided that the corrective action is to change the drilling oil from Regal oil (for SNL/CA products) to a cutting oil with extreme pressure additives. The oil selected was the "50-50" oil currently in use on reservoirs at the KCP. The "50-50" oil is named based on the fact that it is a $50 \%$ mixture of two different oils intended to provide sulfur and chlorine Extreme Pressure (EP) additives in proportions ideal for heavy duty cutting operations such as screw machine and gun drilling operations.

Since the Pinch Weld Quality team did not include representation from LANL a new team was formed to include them. This new team was chartered to address all issues relative to fill stem manufacturing and pinch welding from production agency to design agency. The following tasks and items were accomplished during the initial phase of the work. A screening study with a bold set of machining and welding parameters was completed and represents a significant cooperative effort between the production and design agencies to understand what factors affect pinch welding in an objective manner. In addition "side studies" to determine the effects of atmosphere (Nitrogen or air, Ref. 2), Scratches (Ref. 3), and brushing (Ref. 4) were conducted.

The results indicate that confined pinch welds are extremely robust to significant variations in stem bore manufacturing variable such as drilling rate, forging grain structure, cleaning method (acid etch or not). The un-confined weld proved not to be as robust as the confined weld as was expected. This test data will serve to direct future designs to move to the confined weld whenever possible. Based on these results, the team decided collectively not to pursue testing for optimization for the un-confined weld.

In order to effectively use the samples several innovations were made. These include developing the confined burst test method, learning to EDM samples, and developing Ultrasonic Testing equipment and techniques. To better understand the meaning of bond rating and also to determine the strength of the welds rather than that of the tubing, a constrained burst testing method was developed. This task was successful to the extent we were able to determine that the welds are very strong. In general the welds failed at over 30,000 psi and all the very good welds burst at about 100,000 psi. Some of which still failed in the tube rather than the weld. Due to the constraint, these tube failures were not the traditional side wall burst, rather they were tensile overloads and resulted in the weld being removed from the tube circumferentially.

A method that would permit both a burst and a metallographic sample to be harvested from the same stem using electro-discharge machining (EDM) was developed. The stems were cut near the center of the weld. The suitability of this sectioning method was verified using a metallographic sample preparation technique that removed only a small amount of material 
during the grinding step, i.e., between 0.003 and 0.010 inch. This amount of material removal was sufficient to remove the EDM recast layer and provide a meaningful metallographic sample.

Ultrasonic testing has been proposed for solid state resistance weld inspections for several years. Recent efforts using this approach provided a significant view into the entire closure weld area. Results indicated that the process can easily discriminate between a weld nugget and abnormalities in the bond area. Further study of this method is being considered.

\section{Optimization Study}

Subsequent to the Screening study DOEx, KCP-613-8133 (Ref. 1) and as continuation of the six sigma methodology, an Optimization Study for the Fill Stem Manufacturing and Pinch Weld Processing Study was conducted. Fill stems, similar to the type 304L stainless steel LF-7 reclamation stems, Figure 1, were fabricated using optimal machining parameters from the screening study and drilled with Titanium Carbo-nitride (TiCN) coated drills. These drills had been used to drill either four or five holes in production stems of 21-6-9 stainless steel forgings. The number of holes drilled, the weld parameters, and the stem serial numbers are provided in Table 1. The conditions were selected based on the results of the screening study.

Consistent with the screening study, the welds were made on the SRNL development welder. Prior to welding the stems were examined using a borescope and images were taken at 90 degree intervals in the pinch weld zone. The typical internal surfaces are shown in Figure 2. The KCP inspectors also examined the stems with the comments indicated in Table 1.

Pinch welds were made using a brass piece that simulates the mass of an LF-7 reservoir. The standard confined pinch weld fixturing was used. Hastelloy ${ }^{\mathrm{TM}} \mathrm{X}^{\mathrm{TM}}$ anvils and tungsten tipped copper electrodes were used. The electrodes were modified by machining a flat on one side of the electrode so an acoustic emission (AE) sensor could be mounted. Unlike the screening study in which machine and post weld inspection data were collected, this study included capturing the AE data. These data will be analyzed using algorithms developed under Project NORMAN (Ref. 2) and may also be interrogated using additional methods.

The welded stems were inspected using radiography, dimensional methods, and ultrasonic testing prior to being cut using the EDM, as described above. The dimensional requirements for stems are listed in Table 2. The test weld sections for metallographic examination and bond rating were mounted, polished, etched electrolytically with oxalic acid, and examined at 50 to 500X magnifications. The balance of the stem was used for the constrained burst testing as described in the screening study report and Ref. 5. The bond rating, determined using SOP MTF-4.14 was considered the final arbiter for quality acceptance (Ref. 7). 
I DIAMETRICALLY OPPOSED WALL THICKNESS SHALL BE UNIFORM WITHIN .005 IN THIS ZONE. THIS FEATURE SHALL BE ACCEPTED BY RADIOGRAPHIC INSPECTION PER 1470199.

2 LASER MARK SERIAL NUMBER IN THIS ZONE. MARKING SHALL BE RADIALLY ORIENTED. CHARACTER SIZE OPTIONAL.

\section{LASER MARK SERIAL NUMBER \\ IN THIS ZONE. MARKING SHALL BE LONG I TUDINALLY ORIENTED. CHARACTER SIZE OPTIONAL.}

4. RECORD FORGING INFORMATION ON DF 1470782

5. FORGINGS: $1470217(304 \mathrm{~L})$ $1470234(21-6-9)$

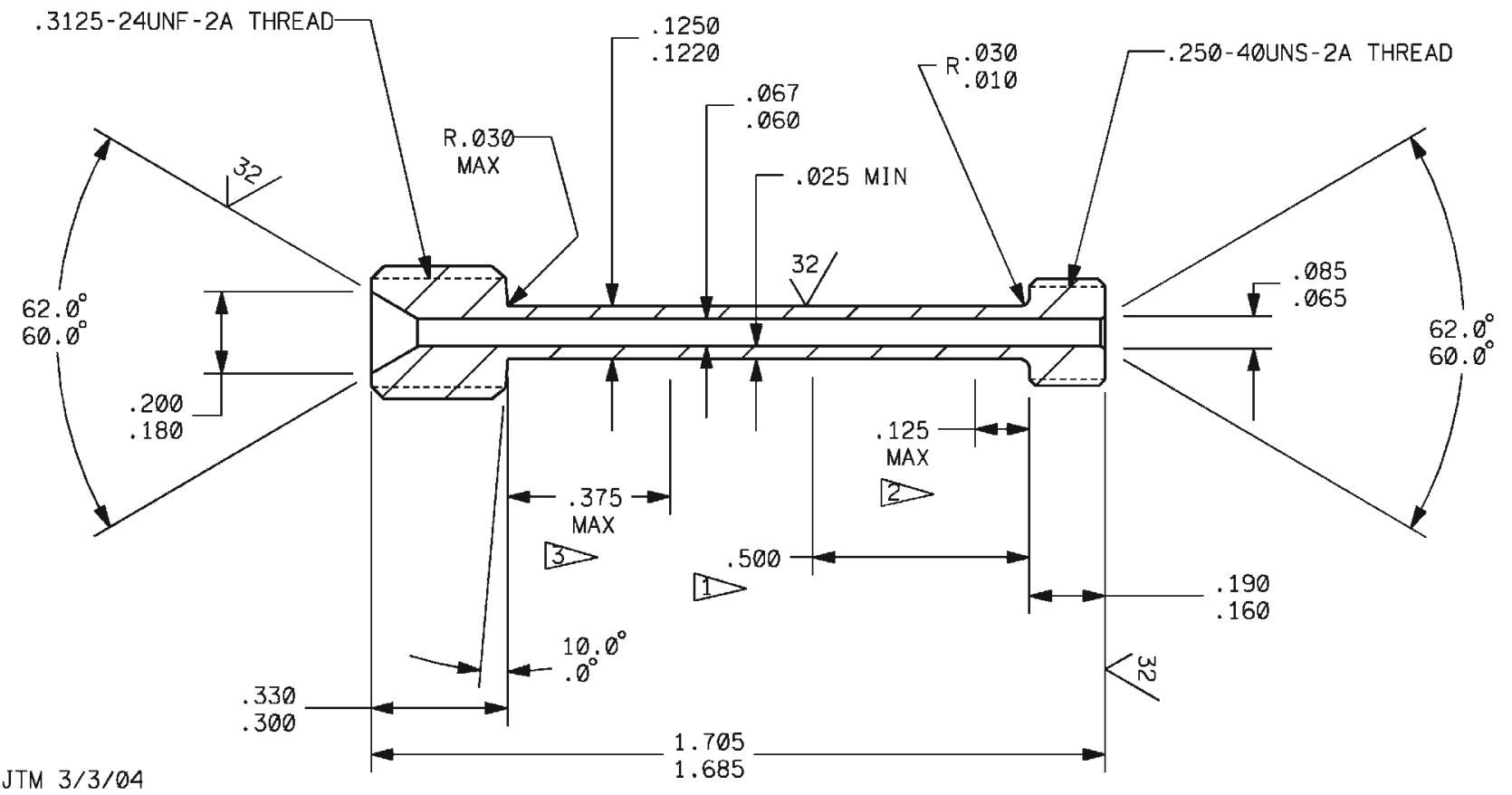

Figure 1. Fill stem based on a modified LF-7 used for the optimization study (PN PRJ706566-102) . 
Table 1. Machining and welding parameters used for this study.

\begin{tabular}{|c|c|c|c|c|c|c|}
\hline Number & Serial & $\begin{array}{l}\text { \# of } \\
\text { Holes }\end{array}$ & Cycles & Current & 0 degree & 90 degree \\
\hline 1 & X0084 & 4 & 13 & 3560 & OK & $\begin{array}{l}\text { O FM } \\
\text { removed }\end{array}$ \\
\hline 2 & X0079 & 5 & 11 & 3840 & $\begin{array}{l}\text { R small } \\
\text { ding on } \\
\text { conical }\end{array}$ & $\begin{array}{l}\text { Dings on } \\
\text { conical }\end{array}$ \\
\hline 3 & X0083 & 4 & 13 & 3840 & OK & OK \\
\hline 4 & X0086 & 4 & 11 & 3700 & OK & OK \\
\hline 5 & X0093 & 5 & 13 & 3700 & $\begin{array}{l}\mathrm{R} \text { dings on } \\
\text { conical }\end{array}$ & $\begin{array}{l}\text { Large ding } \\
\text { on conical }\end{array}$ \\
\hline 6 & X0092 & 5 & 12 & 3500 & OK & OK \\
\hline 7 & X0087 & 4 & 12 & 3900 & OK & OK \\
\hline 8 & X0094 & 4 & 12 & 3700 & OK & OK \\
\hline 9 & X0088 & 5 & 12 & 3700 & OK & OK \\
\hline 10 & X0080 & 5 & 12 & 3700 & OK & $\begin{array}{l}\text { Scratches at } \\
\text { end }\end{array}$ \\
\hline 11 & X0078 & 4 & 11 & 3560 & $\begin{array}{l}\text { Ding on } \\
\text { conical }\end{array}$ & $\begin{array}{l}\text { ding on } \\
\text { conical }\end{array}$ \\
\hline
\end{tabular}

Table 2. Dimensional Requirements for Acceptable Confined Pinch Welds.

\begin{tabular}{|l|l|}
\hline PARAMETER & Acceptable range \\
\hline Weld Thickness (in) & $0.050-0.060^{\star \star}$ \\
\hline Weld Width (in) & $0.135 \mathrm{max}^{\star \star}$ \\
\hline Weld Closure (in) & $0.100\left(^{*}\right)$ Min \\
\hline Extrusion Height/Base Ratio & $<1.0\left(^{(}\right)$ \\
\hline No Extrusion Weld Root (in) & $>0.010\left(^{*}\right)$ \\
\hline Wall Thickness (in) & $0.020\left(^{*}\right)$ Min \\
\hline
\end{tabular}

(*) Indicates a Requirement for WR Acceptance (**) Operational Limits

\section{Results}

\section{Borescopic Inspection}

No significant defects or anomalies were observed in the pinch weld zone by borescope inspection Figure 2. Some anomalies were indicated on the conical region as signified by the " $\mathrm{R}$ " in the 0 degree column of Table 1, these two stems did not meet WR requirements because of these conical anomalies but were acceptable for the optimization study. 


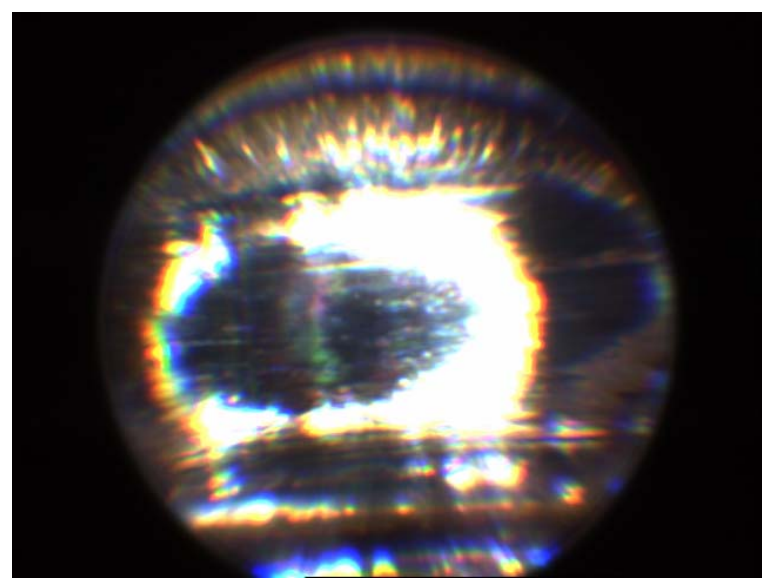

(a)

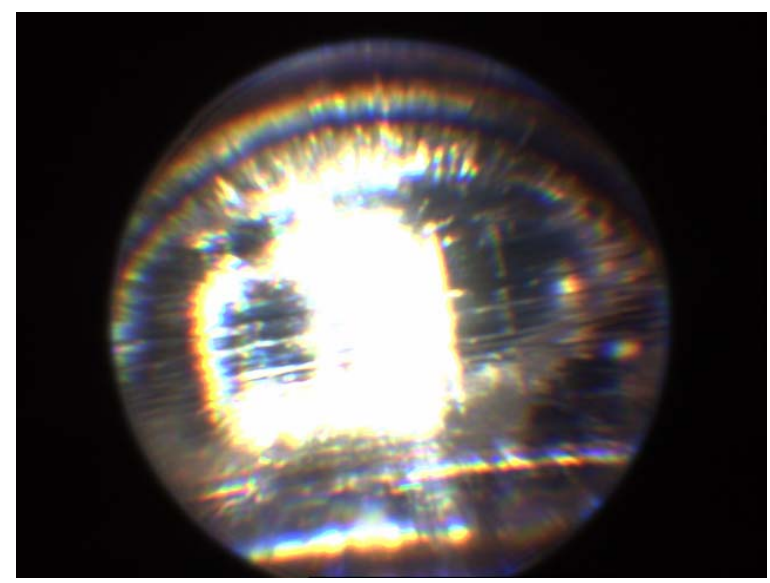

(b)

Figure 2. Internal surface of fill stems (a) X0084 and (b) X0079 stems machined with coated drills that were used to drill 4 and 5 holes, respectively.

\section{Weld Results}

The stems were welded with the actual conditions and results indicated in Table 3. The first section of Table 3 indicates the result from most of the non destructive inspection and testing while the latter half is comprised of data from destructive sample preparation and testing. Nearly all of the welds were made less than 10 amperes from the target with all but one less than $20 \mathrm{~A}$ from the target. The welds met all the requirements for WR inspection although somewhat more melting was observed in the samples than what is desired. There is no specific amount of melting either prohibited or encouraged. Excessive melting is often associated with parameters that are close to forming weld expulsions and are avoided for this reason. The maximum extrusion is also an indicator of weld heat and it is desirable to have between 0.008 and 0.012 inch extrusion although there are no WR requirements.

There is a WR requirement that the extrusion ratio (extrusion length/base) be less than one. The closure length, net displacement, and extrusion length all increase with increased current, as shown in Figure 3. The bond ratings generally improve (lower is better) with increased current and the thickness is reduced. The burst results are more difficult to generalize since there were more tube failures than weld failures, as shown in Figure 4. Three samples failed through the weld at the low current and one at the mid current level. The weld failures all occurred on samples that did not exhibit melting and yet had bond ratings of 2 , while all of the tube failures exhibited some melting. This result does not suggest any issues with the weld quality since the unrestrained burst pressure is about 60-65 ksi. The lower burst pressure does suggest that the weld strength increases with melting, however, there are other potential adverse metallurgical and processing issues related to melting and potentially excessive melting. Consequently, a balance between these counteracting effects must be established. 
WSRC-STI-2006-00158 Optimization Study for Fill Stem $\quad$ Page 7 of 32

Rev. 1

Manufacturing and Pinch Weld Processing

Table 3. Weld parameters and results for the stems welded for the optimization study.

\begin{tabular}{|l|l|l|l|l|l|l|l|l|l|}
\hline & Cycles & $\begin{array}{l}\text { Current } \\
\text { (A) }\end{array}$ & $\begin{array}{l}\text { Force } \\
\text { (Ibs) }\end{array}$ & $\begin{array}{l}\text { Weld } \\
\text { (V) }\end{array}$ & $\begin{array}{l}\text { Net D } \\
\text { (in) }\end{array}$ & $\begin{array}{l}\text { Closure } \\
\text { Length } \\
\text { (in) }\end{array}$ & $\begin{array}{l}\text { Max } \\
\text { Extr. } \\
\text { (in) }\end{array}$ & $\begin{array}{l}\text { Extru. } \\
\text { Ratio }\end{array}$ & comments \\
\hline X0084 & 13 & 3573.9 & 1255.9 & 0.7680 & 0.0191 & 0.1598 & 0.0037 & 0.17 & \\
\hline X0079 & 11 & 3839.0 & 1255.7 & 0.8300 & 0.0201 & 0.1694 & 0.0121 & 0.43 & Split Closure \\
\hline X0083 & 13 & 3860.6 & 1257.2 & 0.8155 & 0.0229 & 0.1796 & 0.0149 & 0.49 & Split Closure \\
\hline X0086 & 11 & 3701.2 & 1251.7 & 0.8098 & 0.0200 & 0.1615 & 0.0084 & 0.35 & Split Closure \\
\hline X0093 & 13 & 3718.0 & 1257.3 & 0.7973 & 0.0209 & 0.1721 & 0.0101 & 0.38 & \\
\hline X0092 & 12 & 3500.3 & 1257.6 & 0.7797 & 0.0192 & 0.1515 & 0.0020 & 0.11 & Split Closure \\
\hline X0087 & 12 & 3908.8 & 1255.5 & 0.8338 & 0.0221 & 0.1812 & 0.0168 & 0.55 & Split Closure \\
\hline X0094 & 12 & 3710.9 & 1255.0 & 0.8012 & 0.0203 & 0.1669 & 0.0097 & 0.38 & Split Closure \\
\hline X0088 & 12 & 3709.9 & 1255.6 & 0.8103 & 0.0205 & 0.1687 & 0.0122 & 0.45 & Split Closure \\
\hline X0080 & 12 & 3710.6 & 1255.3 & 0.8004 & 0.0210 & 0.1686 & 0.0095 & 0.36 & \\
\hline X0078 & 11 & 3567.0 & 1255.3 & 0.7789 & 0.0182 & 0.1489 & 0.0017 & 0.10 & Split Closure \\
\hline
\end{tabular}

Table 3 cont.

\begin{tabular}{|c|c|c|c|c|c|c|}
\hline ID & $\begin{array}{l}\text { Rem Closure } \\
\text { (in) }\end{array}$ & $\begin{array}{l}\text { Burst Pressure } \\
\text { (ksi) }\end{array}$ & $\begin{array}{l}\text { Failure } \\
\text { Location }\end{array}$ & BR & Comments & $\begin{array}{l}\text { Thick* } \\
\text { (in) }\end{array}$ \\
\hline X0084 & 0.053 & 115.74 & Weld & 2 & Discontinuous line & 0.047 \\
\hline X0079 & 0.056 & 119.71 & Tube & 1 & Nugget & 0.047 \\
\hline X0083 & 0.076 & 115.96 & Tube & 1 & Nugget & 0.046 \\
\hline X0086 & 0.064 & 109.7 & Weld & 2 & Discontinuous line & 0.048 \\
\hline X0093 & 0.065 & 113.75 & Tube & 2 & $\begin{array}{l}\text { Discontinuous line with } \\
\text { melting }\end{array}$ & 0.046 \\
\hline X0092 & 0.045 & 108.52 & Weld & 2 & Discontinuous line & 0.049 \\
\hline X0087 & 0.053 & 116.94 & Tube & 1 & Nugget & 0.046 \\
\hline X0094 & 0.071 & 116.18 & Tube & 2 & $\begin{array}{l}\text { Discontinuous line with } \\
\text { melting }\end{array}$ & 0.046 \\
\hline$\times 0088$ & 0.053 & 114.93 & Tube & 2 & $\begin{array}{l}\text { Discontinuous line with } \\
\text { melting }\end{array}$ & 0.047 \\
\hline $\mathrm{X0080}$ & 0.056 & 119.35 & Tube & 2 & $\begin{array}{l}\text { Discontinuous line with } \\
\text { melting }\end{array}$ & 0.048 \\
\hline $\mathrm{X0078}$ & 0.051 & 112.72 & Weld & 2 & Discontinuous line & 0.048 \\
\hline X0081 & 0.037 & 122.04 & Tube & 2 & Discontinuous line & 0.051 \\
\hline
\end{tabular}




\section{Weld Quality Metrics}

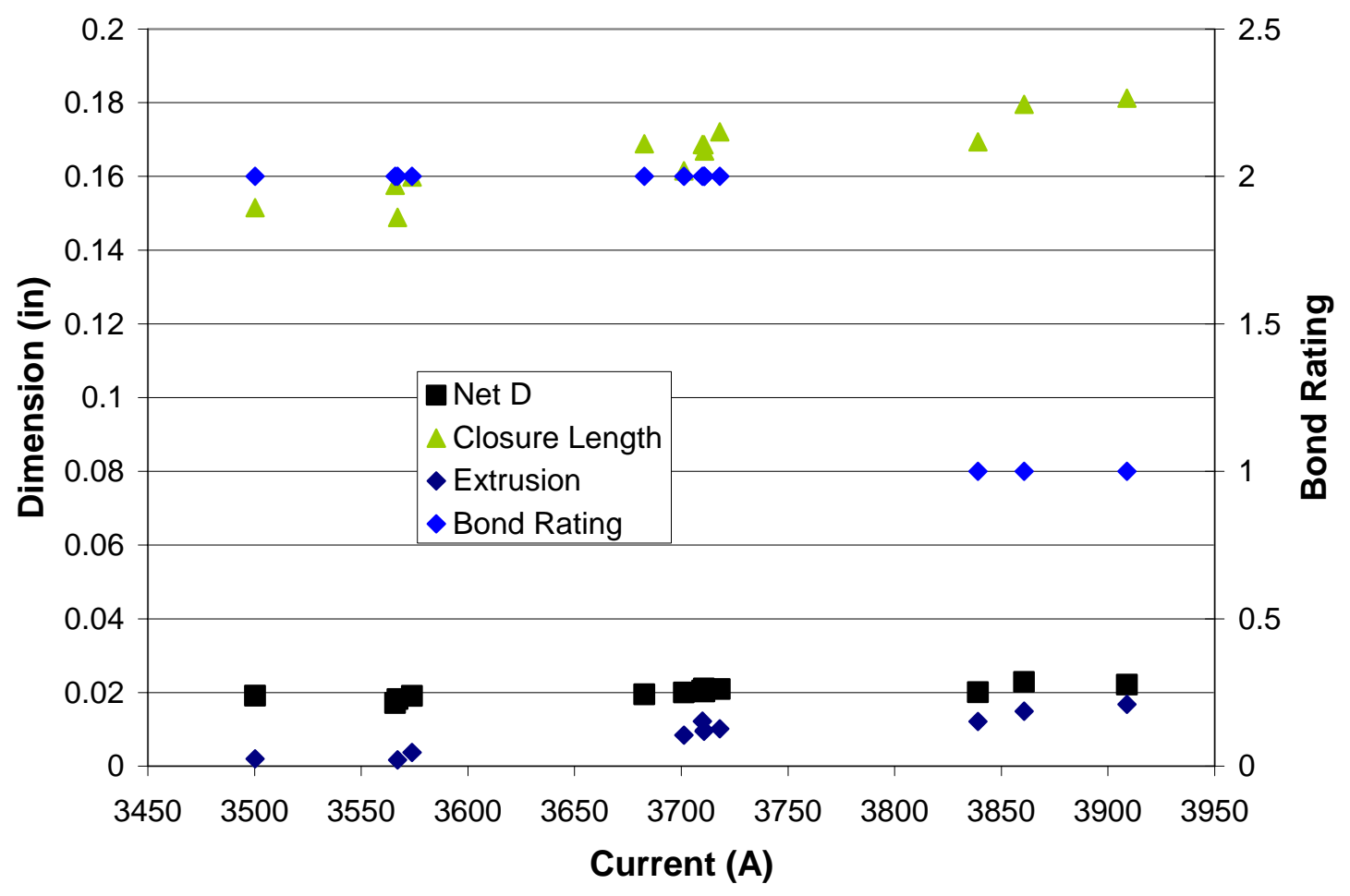

Figure 3. Weld quality metrics as a function of current

\section{Metallographic Results}

Metallographic examination of the pinch welds show both solid state and partial melting as indicated in Table 3. Micrographs of the 12 cycle welds made at nominally 3500, 3700, and 3900 A are shown in Figure 5. These images demonstrate the different microstructures obtained from this study and show a solid state discontinuous bond at the lowest weld current to a significant nugget at the highest weld current. The intermediate current condition exhibits some melting but not an excessive amount and the bond line is still partially visible. Micrographs of all the weld samples are in Appendix A. 
WSRC-STI-2006-00158 Optimization Study for Fill Stem

Page 9 of 32

Rev. 1

Manufacturing and Pinch Weld Processing

Pinch Weld Quality Metrics

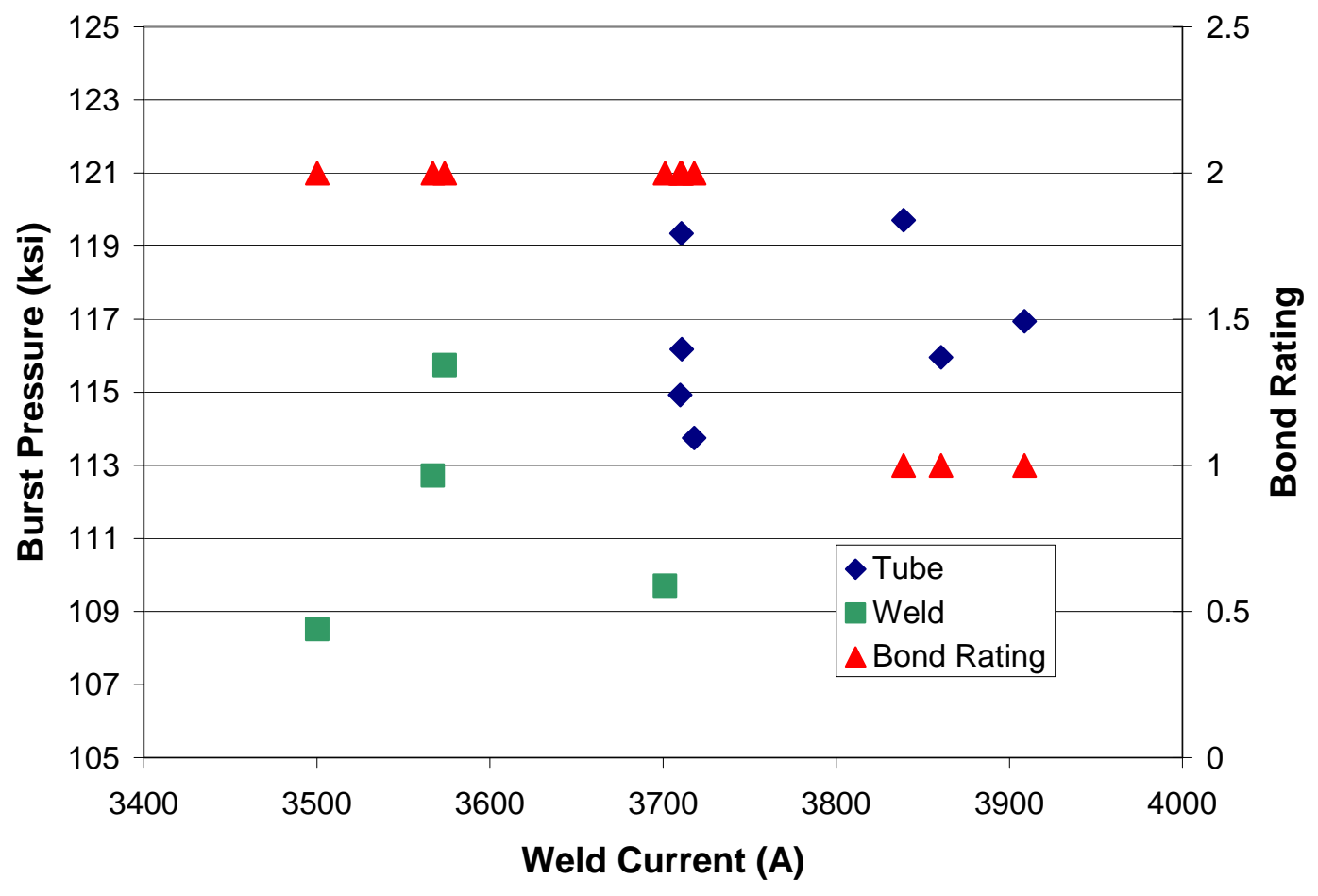

Figure 4. Destructive weld quality metrics bond rating and burst strength. 
Rev. 1
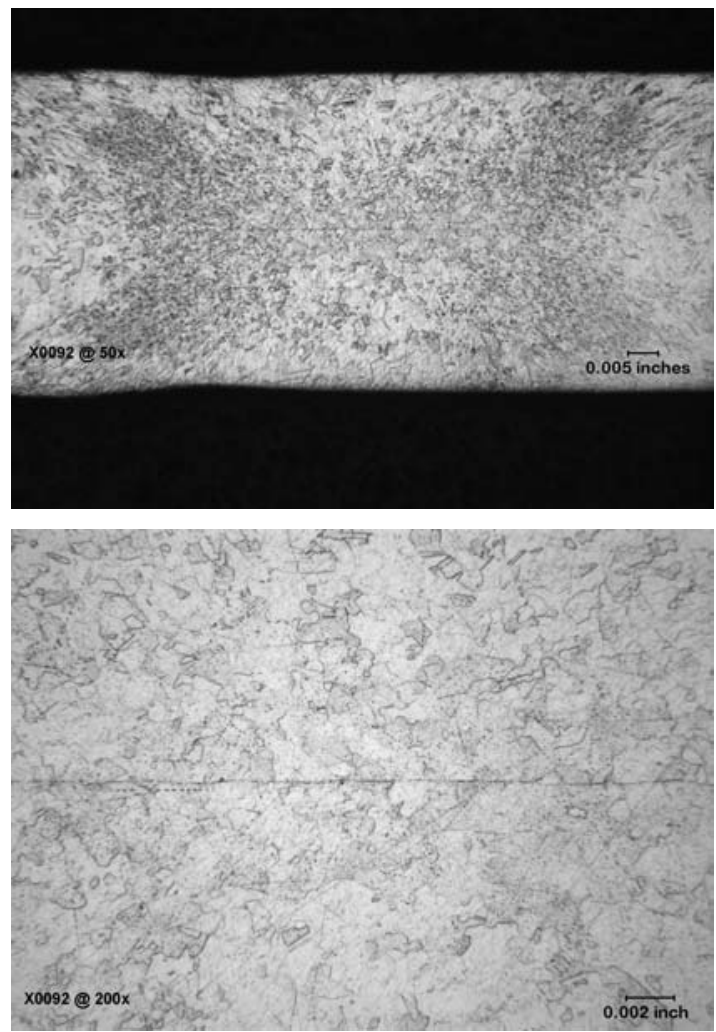

(a) 12 cycles / 3500 A / 1258 lbs, X0092
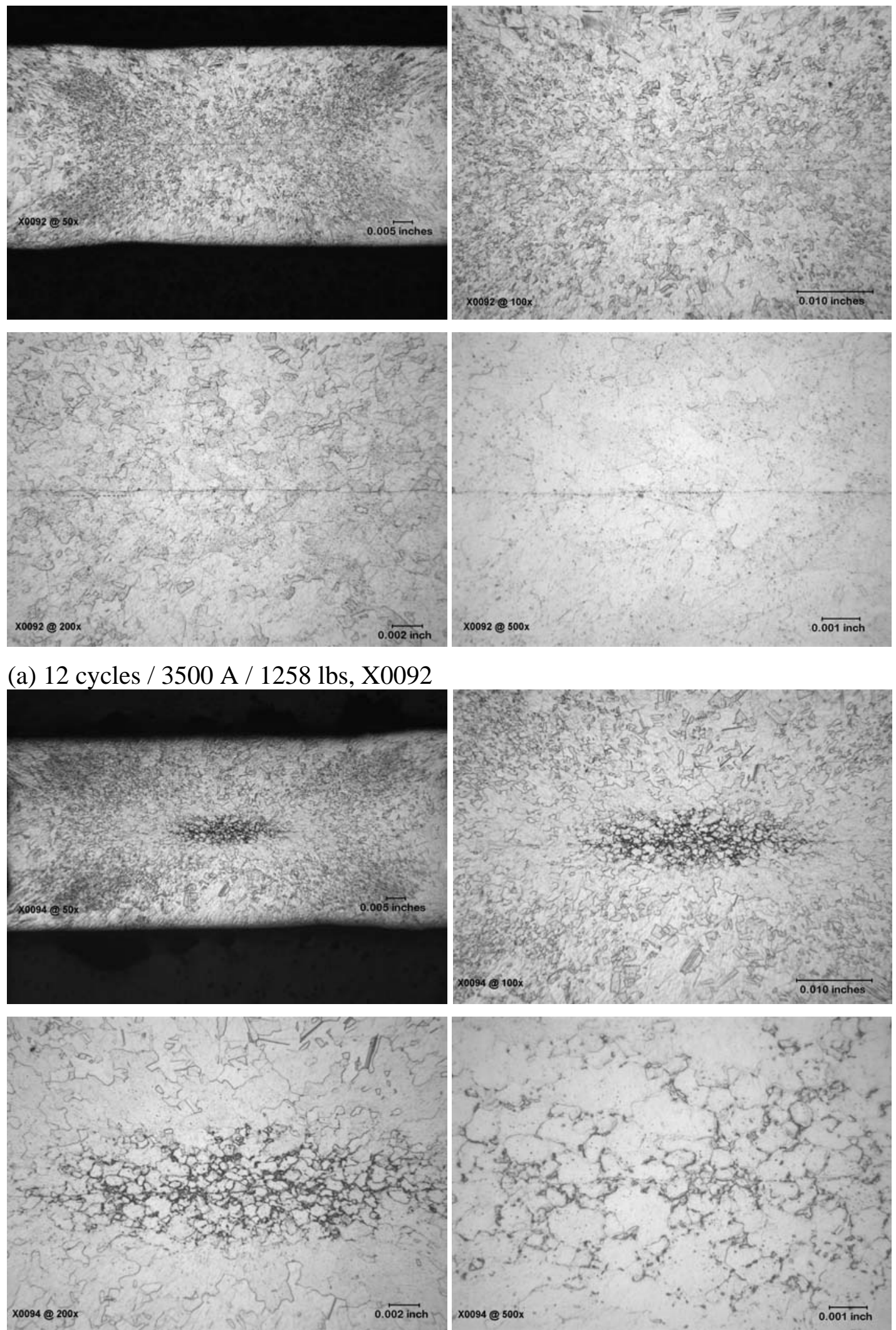

(b) 12 cycles / 3711 A / 1255 lbs, X0094 

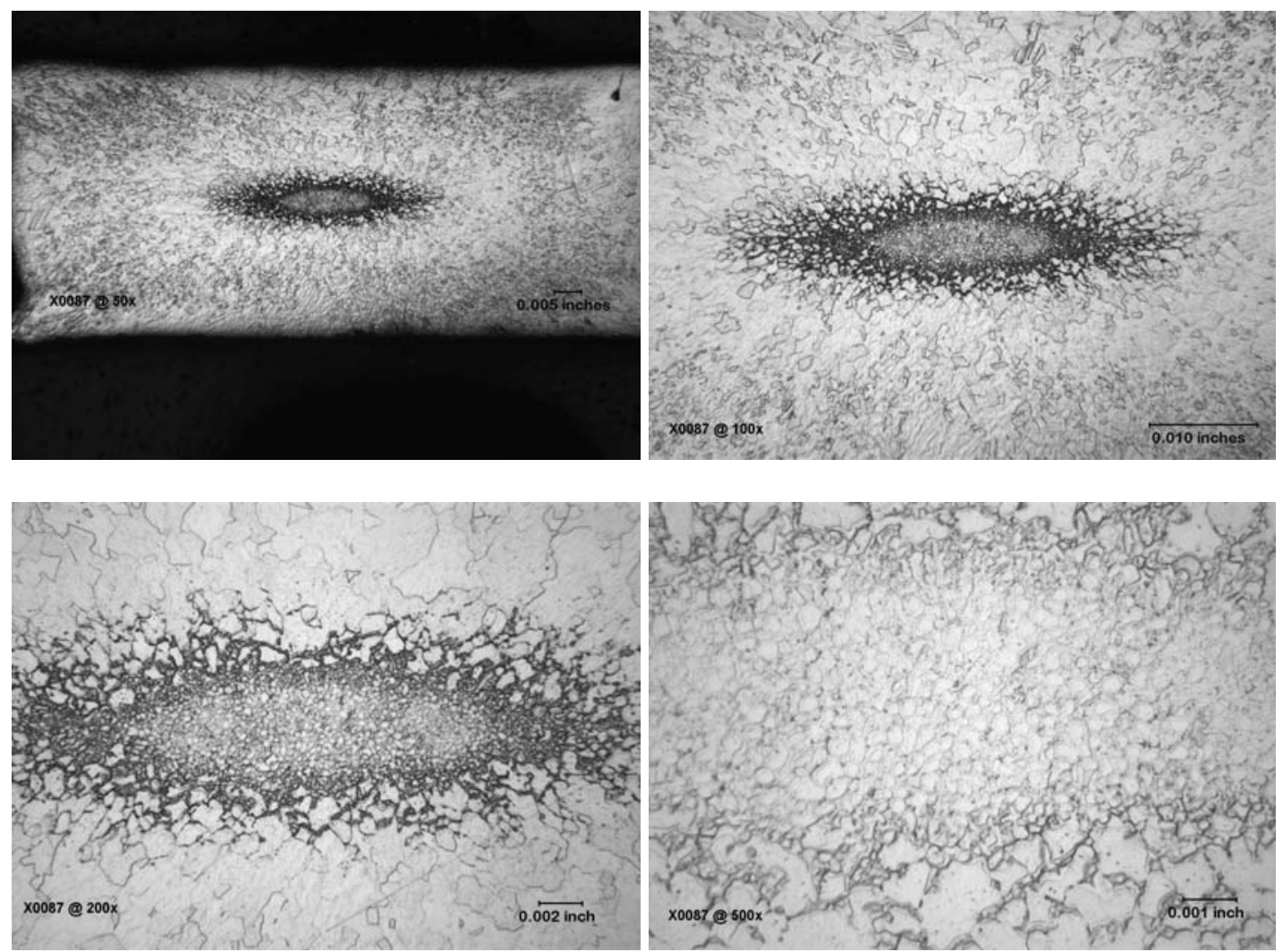

(c) 12 cycles / 3909 / 1255 lbs, X0087

Figure 5. Micrographs at multiple magnifications showing the structures of the welds for samples produced at (a) 12 cycles / 3500 A / 1258 lbs, X0092 (b) 12 cycles / 3711 A / 1255 lbs, X0094 (c) 12 cycles / 3909 / 1255 lbs, X0087.

\section{Acoustic Emission}

Typical acoustic emission data traces for the weld (on-heat) and a period of time of six seconds from the start of the weld (on-heat, cooling and relaxation) are shown in Figure 6. There are several characteristics that have been considered previously in an attempt to extract weld quality metrics from the acoustic emission data. The most significant difference between the previous work and the recent work is that the recent work has not used the acoustic signal during welding (on heat) to determine the weld quality, rather the data occurring during cooling and relaxation are interrogated. The AE data from this experiment have not been analyzed at this time, but $\mathrm{AE}$ data from two statistically designed experiments that used tubing rather than stems have been evaluated and the results from one study has been published in Ref. 6. Two distinct algorithms were developed to characterize the AE data sets, which indicate further work is needed.

However, bond quality could be ascertained using serial comparisons of the data and appropriate "binning" of the samples with a success ratio of approximately 85\% for the first DOEx and over $60 \%$ for the second. These results are clearly not production ready but there is better understanding of the process and a comprehensive tool may be developed that will allow for in process, non-destructive bond rating assessments to be made. Preliminary examination of these data indicate that yet another acoustic signature was observed and these pinch welds on stems are 
"quieter" than the pinch welds made on tubing. Since no analysis has been conducted these are just observations. AE data collection and data analysis are planned for the validation study that will be conducted in the inert facility of DP at SRS.

Weld 03: ai.00.079

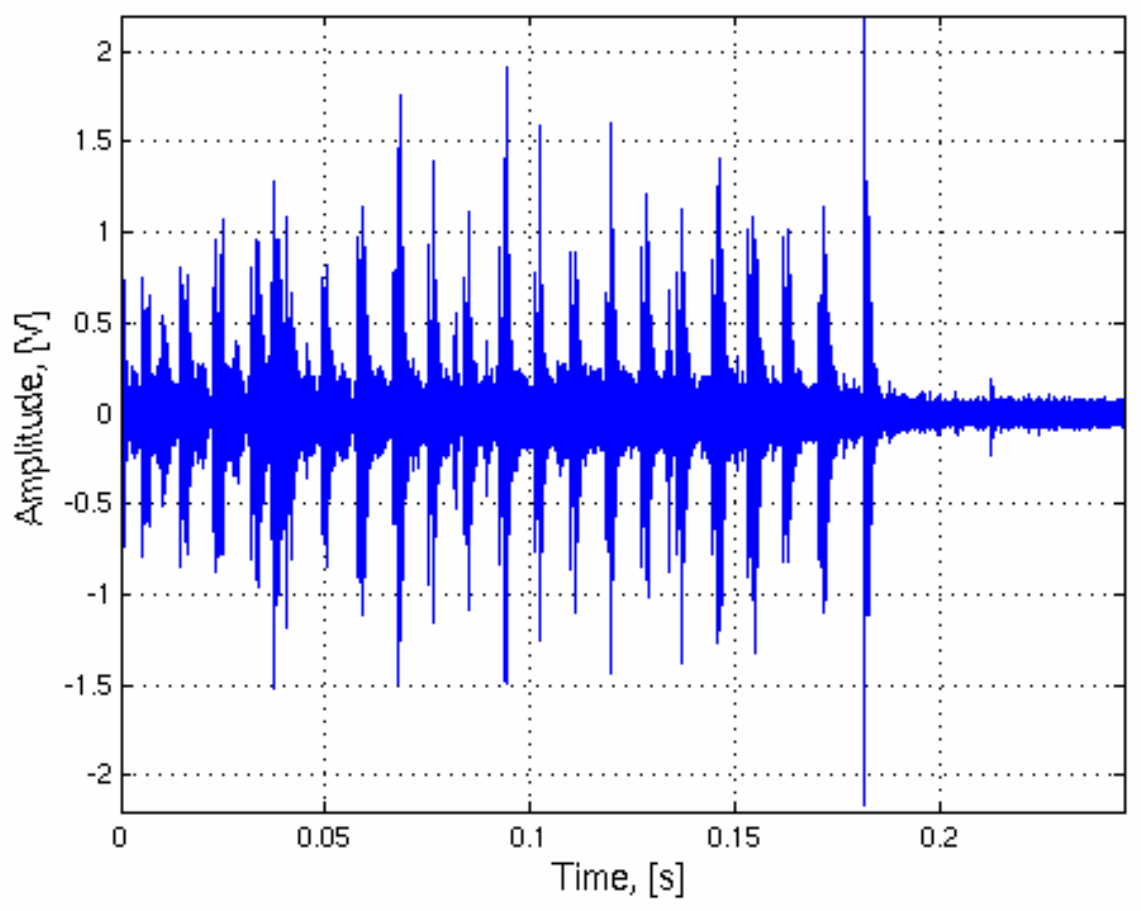

(a)

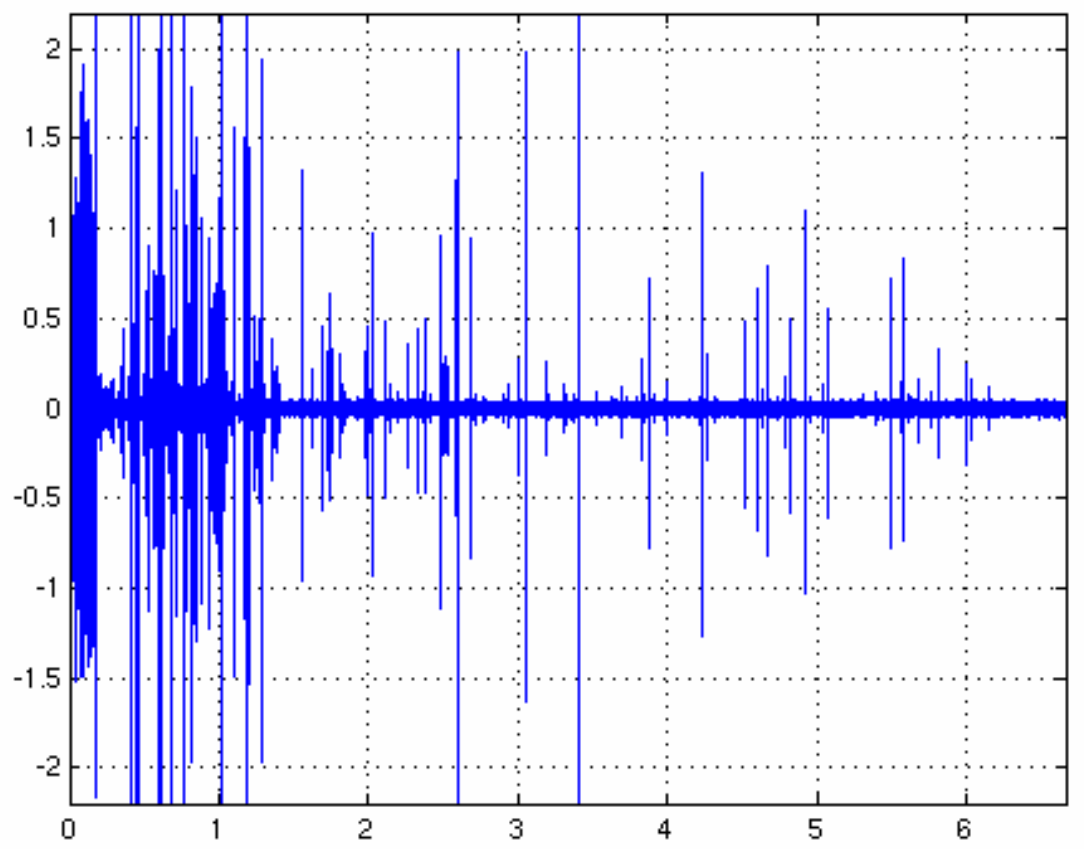

(b)

Figure 6. Acoustic Emission (AE) data collected (a) during the weld (on heating) and (b) for a period of six seconds (on heating, cooling, and relaxation). 


\section{Statistical Analysis}

The optimization experiment used the results of the bold (i.e., wide variation in process parameters) screening experiment to focus on those stem processing variables identified by the screening experiment as CRITICAL to an acceptable pinch weld bond rating. The purpose of a screening experiment is to include the variables that all experts believe to be very important to a successful pinch weld. In this case the screening experiment included manufacturing variables; drill speed, feed, cleaning, grain structure and welding variables; current, force, time, and atmosphere. Results of the screening experiment indicated the only variables that had a statistically significant impact on bond rating were current and time (cycles). Therefore the optimization experiment was designed to focus on the weld variables of current and cycles.

The optimization study was a central composite design with three levels of current and cycles to determine if there was a non-linear response between these critical variables. Within this experimental group, the stems were also drilled with a coated gun drill and multiple holes per drill to establish if there was any significant effect assignable to how many holes a given drill produces. Earlier gun drilling required one drill per hole and this policy has only just recently been modified to allow a drill to produce more than one hole.

Stem manufacturing variables were held at the nominal of drilling at 11,000 RPM with a feed of $3 \mathrm{ipm}$ on the new Nagel twin spindle gun drilling machine using a Titanium Carbonitride (TiCN) coated carbide gun drill and the KCP 50-50 cutting oil. The best 304L forging (1470217-104) and the standard pinch weld test stem configuration (PRJ706566-102) were used in the optimization study. The finished stems were cleaned with the aqueous method per 1470575. Eleven specimens were welded at SRNL at the parameters listed in Table 1.

All welds produced for the optimization study resulted in acceptable bond ratings. Optimization was performed for bond rating, constrained burst as well as non-destructives measurements routinely taken on WR product by direct measurement and dimensions measured directly and by radiography. 


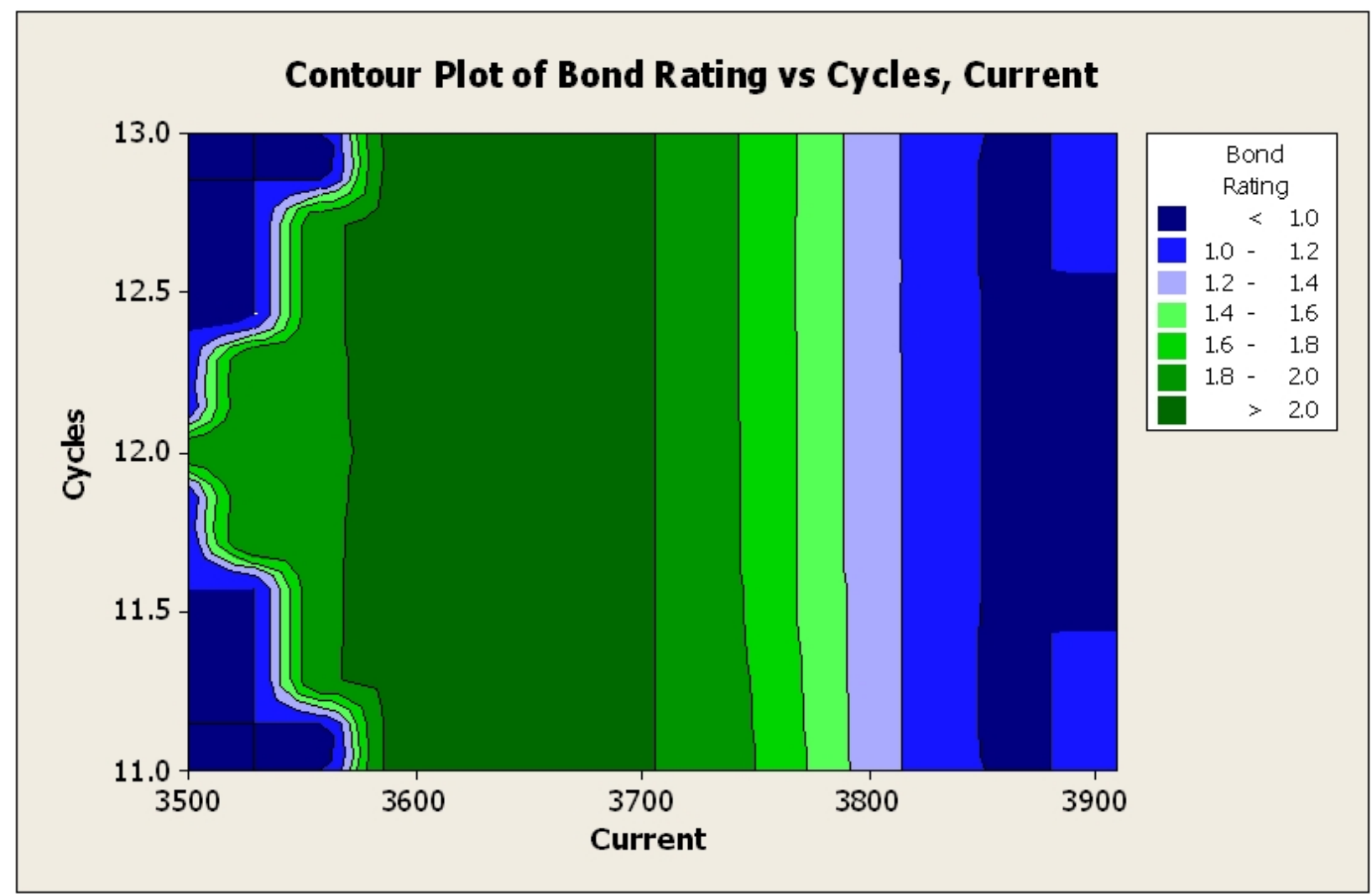

Figure 7. Contour Plot of Pinch Weld Bond Rating Vs. Optimization Parameters Cycles and Current.

Results indicated that a bond rating of 1.0 - 1.2 could be realized at a current greater than 3825 amps for all cycles $(11,12, \& 13)$. Unfortunately, a bond rating of 1.0 does not necessarily represent the best possible weld. In most cases a bond rating of 1.0 would involve some intergranular melting which is commonly referred to as a "nugget". The welding experts agree that you can rarely achieve a 1.0 bond rating without some nugget formation. SNL/CA has stated in their pinch welding specification that "a nugget is to be avoided". Given the constraint to avoid nugget formation, as well as the risk of weld expulsion at the higher amperages, the team negotiated 3750 amps at 12 cycles as the optimum welding amperage based on previous experience. Optimizing on 3750 amps and 12 cycles is equivalent (as shown by the contour plot for bond rating Vs cycles and current) to optimization on a bond rating of $1.6-1.8$. This optimized weld schedule will meet the requirements of closure length, wall thickness, maximum extrusion, extrusion ratio, and thickness. This optimized amperage of 3750 amps will be used in the validation study. 


\section{Summary and Conclusions}

An optimization experiment was successfully completed for the Fill Stem Manufacturing and Pinch Weld Processing Project. The optimization experiment was performed using fill stems that were aqueous cleaned only and were produced as the fourth or fifth hole per drill. The welding process yielded successful welds at all levels of current (3500 - 3900 amps) and cycles (11-13). This supports the previous conclusions that the pinch weld process is extremely robust.

The data revealed trends that are consistent with the expectation that higher current welds result in many attractive pinch weld attributes including better bond ratings and higher weld burst pressure. Other metallurgical and processing considerations limit the extent of nugget formation desired and cause the ideal weld to be optimized at a value other than a 1 bond rating. This result could require a rethinking of the bond rating scale to afford a larger acceptability region than currently allowed if nugget formation is not desirable.

Acoustic Emission testing using stems provides a different acoustic signature than that observed using WR-tubing of varying hardness.

As is expected, the highest current tested produced a weld with a cleaner interface, a finite weld nugget, the longest extrusion, and the highest burst strength.

A validation study using the production equipment should be conducted to verify the optimized weld parameter range will produce bond ratings of 1 o 2 using production tooling on a number of different weld stations. This experiment will incorporate the variability of the weld stations.

\section{References}

1. Arnold, K.F. and Korinko, P. "Nuclear Weapons Complex Screening Experiment to Identify Variables Critical to Stem Closure Welds, KCP-613-8133, Distributed May 06, Topical report for 706566.

2. WSRC-TR-2005-00433, Effect of Atmosphere on Pinch Weld Quality, P.S. Korinko, Sept. 2005.

3. WSRC-TR-2005-00435, Effect of Scratches on Pinch Weld Quality, P.S. Korinko, September 2005. (11-10-05)

4. WSRC-TR-2005-00436, Effect of Brushing on Pinch Weld Quality, P.S. Korinko, September 2005. (12-15-05).

5. SRT-IES -2004-00015, History Of Burst Test Development For Fill Stems, W. Dean Thompson, March 18, 2004.

6. LA-UR 05-6057, In-Process Monitoring of Pinch Welding: An Investigation into a Bond Quality Metric, D.A. Hartman, P.S. Korinko, N.R. Tolk, S.H. Malene, M.G. Smith, M.J. Cola, V.R. Dave', J.P. Miller, W.H. King, in Proceedings from the 7th International Conference on Trends in Welding Research, May 16-20, 2005 -- Pine Mountain, GA.

7. SOP MTF-4.14, Rev. 3. Metallurgical Evaluation of Pinch Weld Bonds (U). 


\section{Appendix A}

Micrographs of fill stems welded for this Optimization Study.
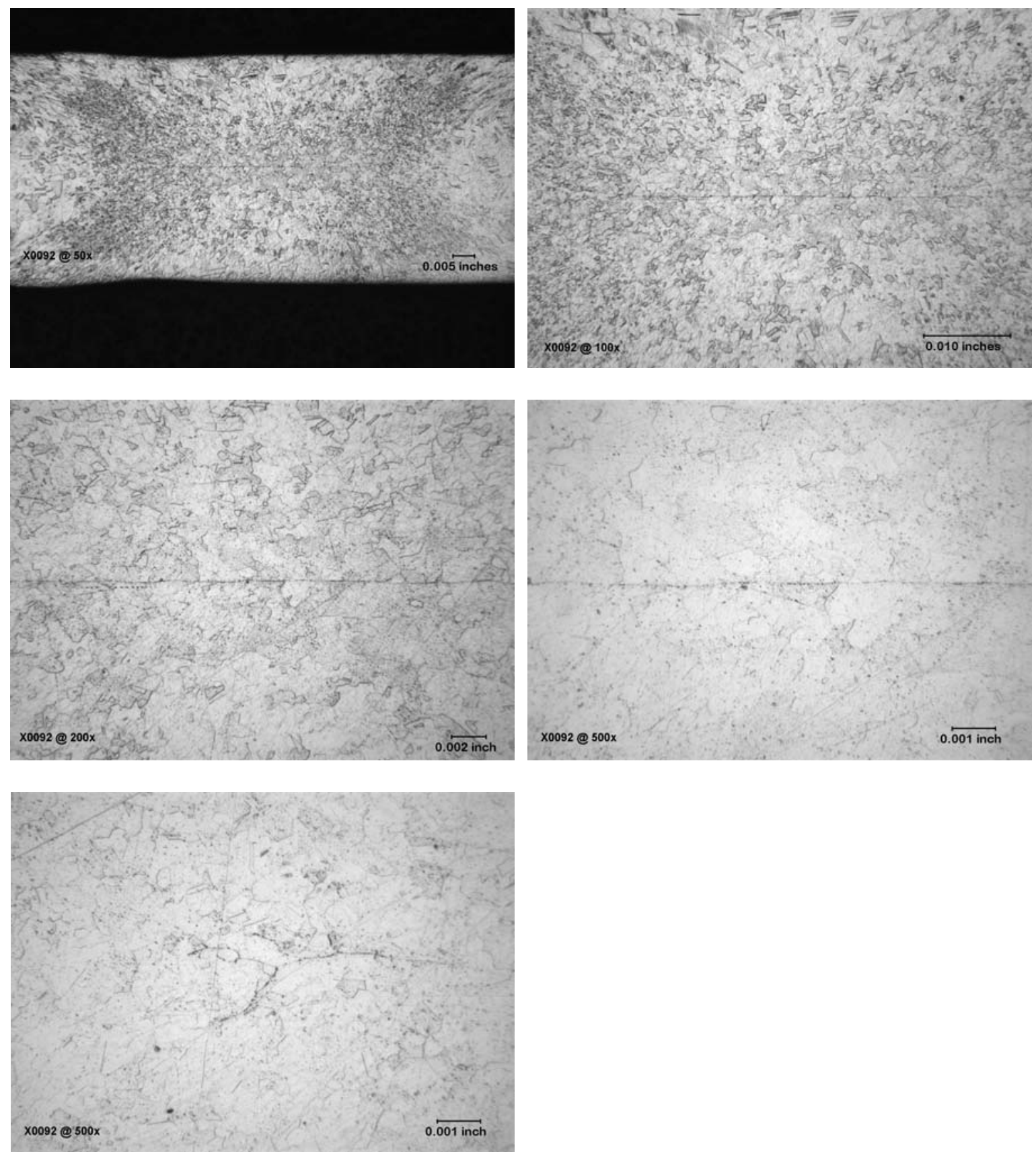

Figure A. 1 X0092, 3500 A, 12 Cycles, 1258 lbs, BR 2 
Rev. 1
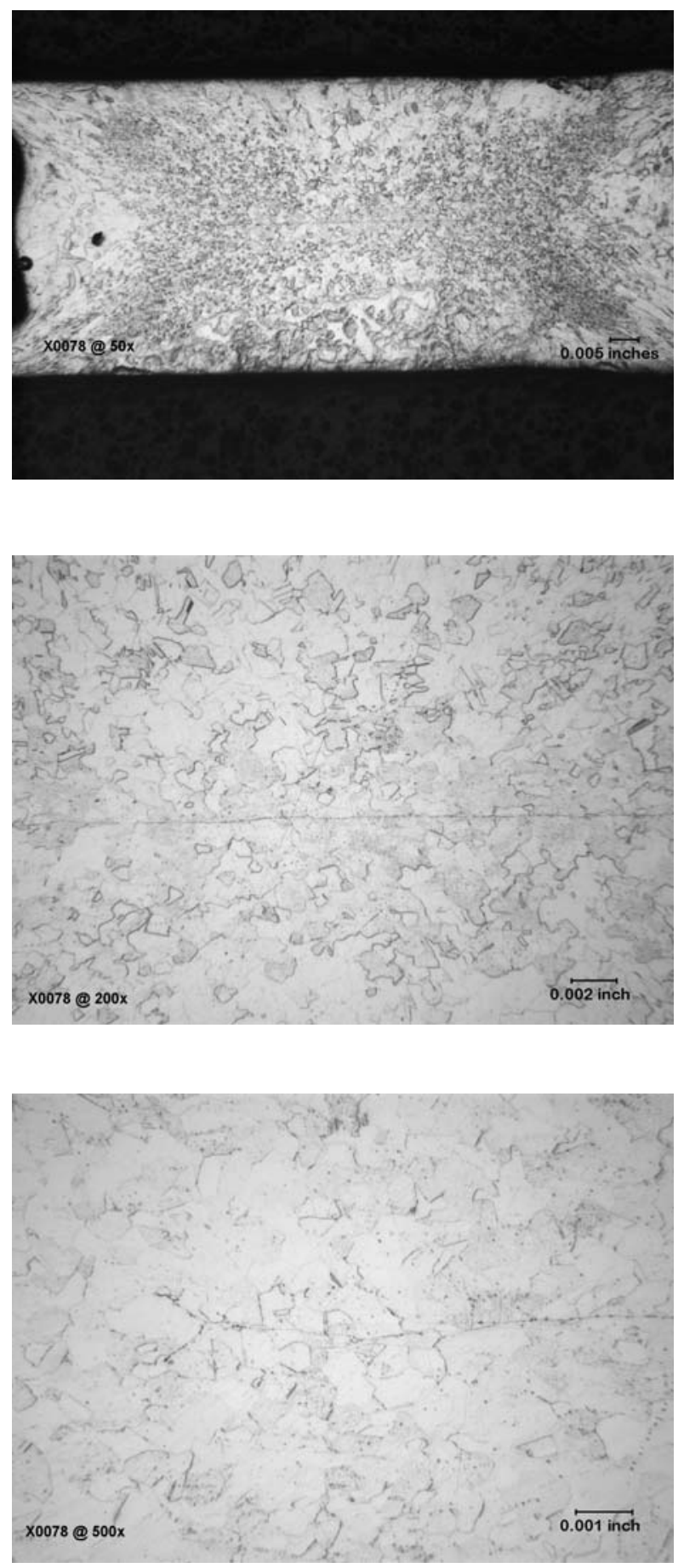

Figure A. 2 X0078, 3567 A, 11 Cycles, 1255 lbs, BR 2
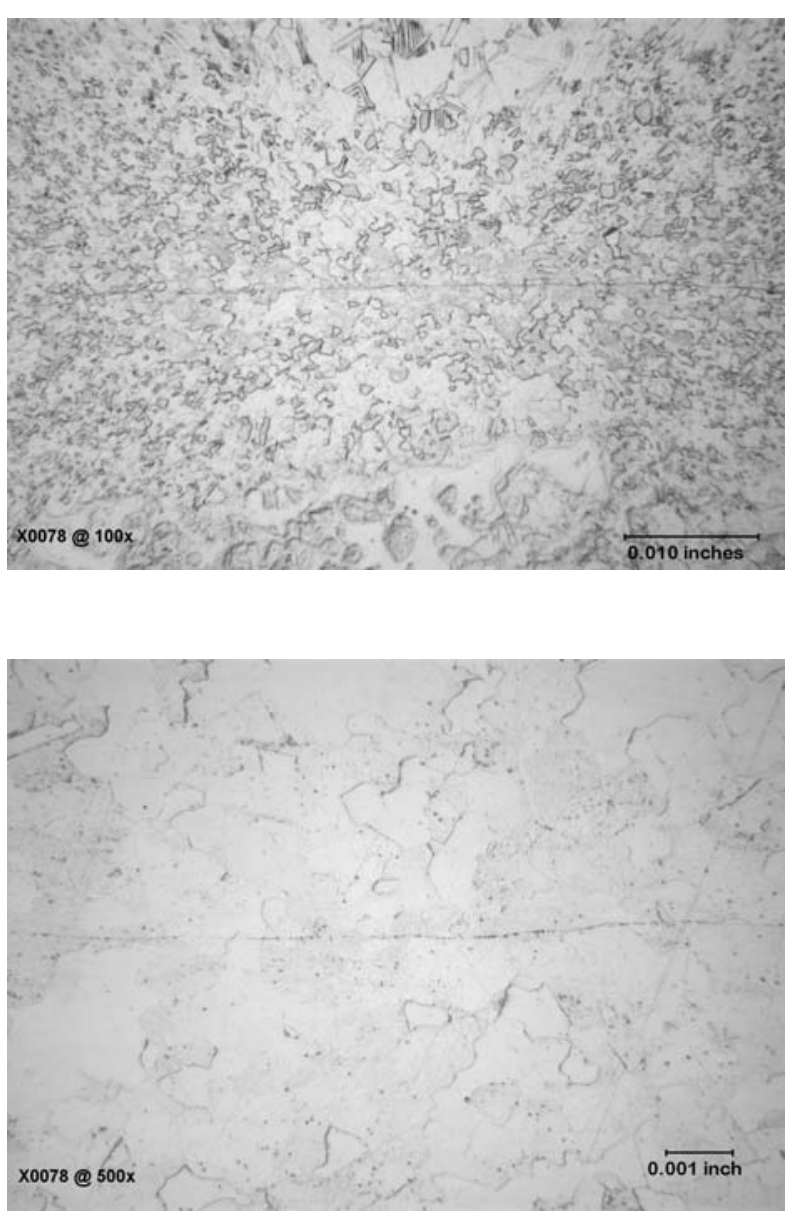

\section{Manufacturing and Pinch Weld Processing}


Rev. 1
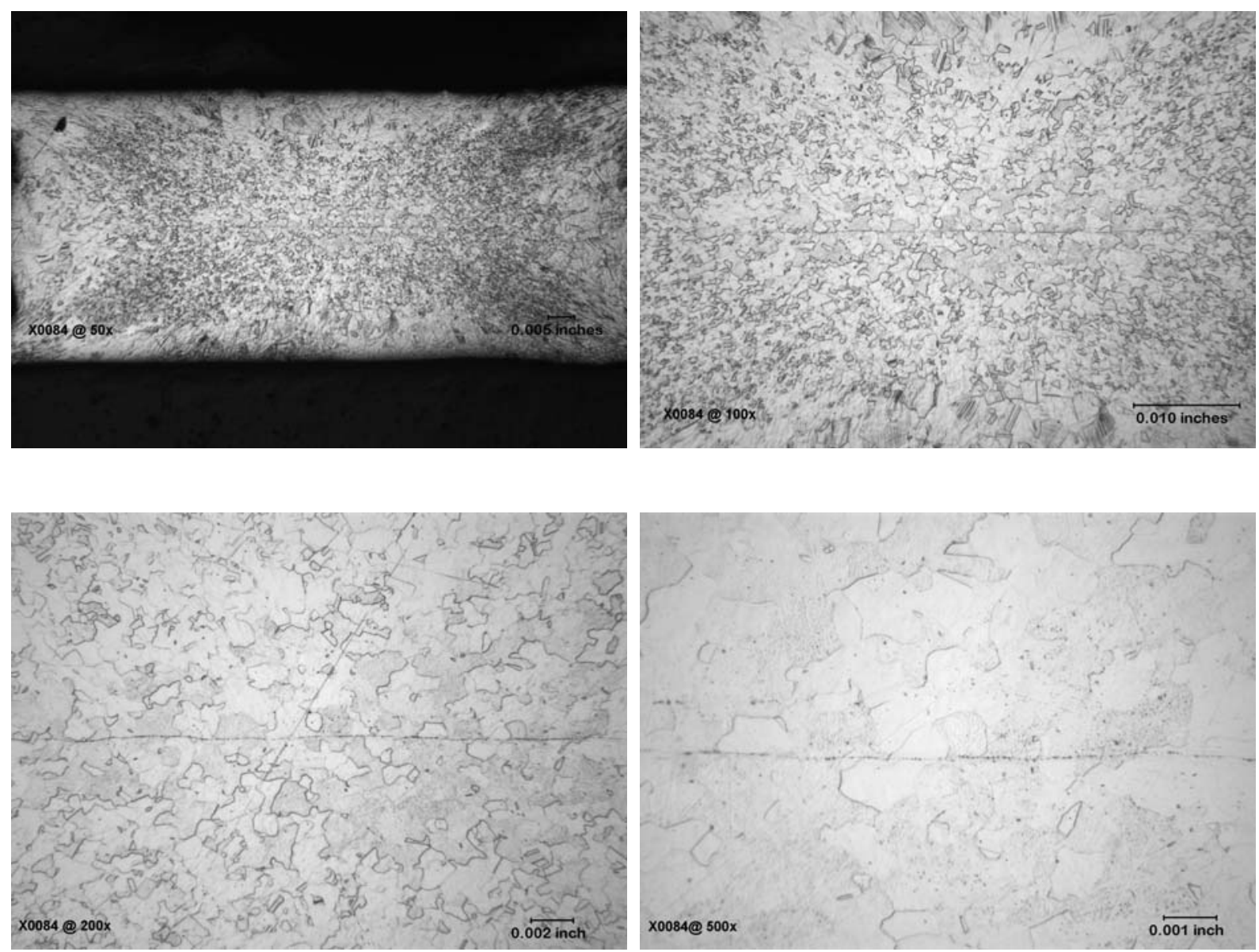

Figure A. 3 X0084, 3574 A, 13 Cycles, 1256 lbs, BR 2 
Rev. 1
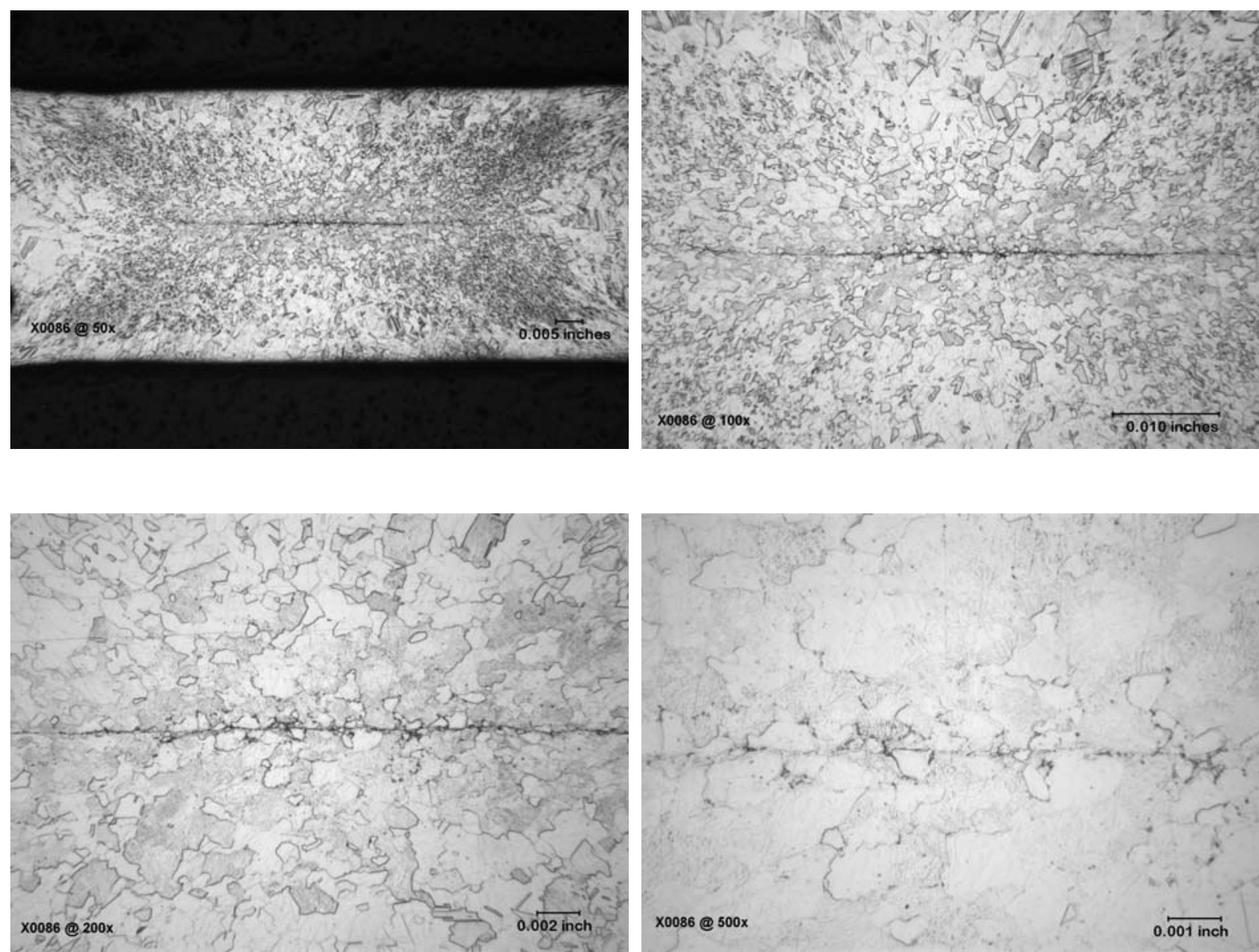

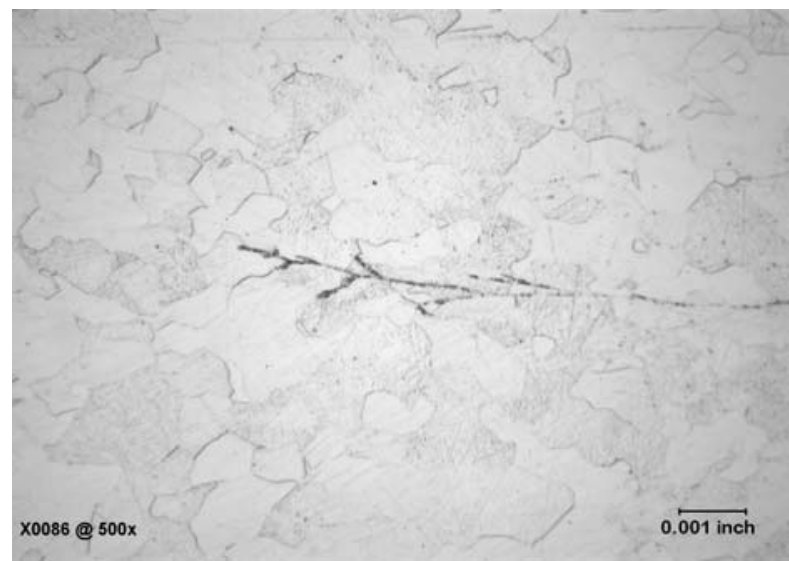

Figure A. 4 X0086, 3701 A, 11 Cycles, 1252 lbs, BR 2 
Rev. 1
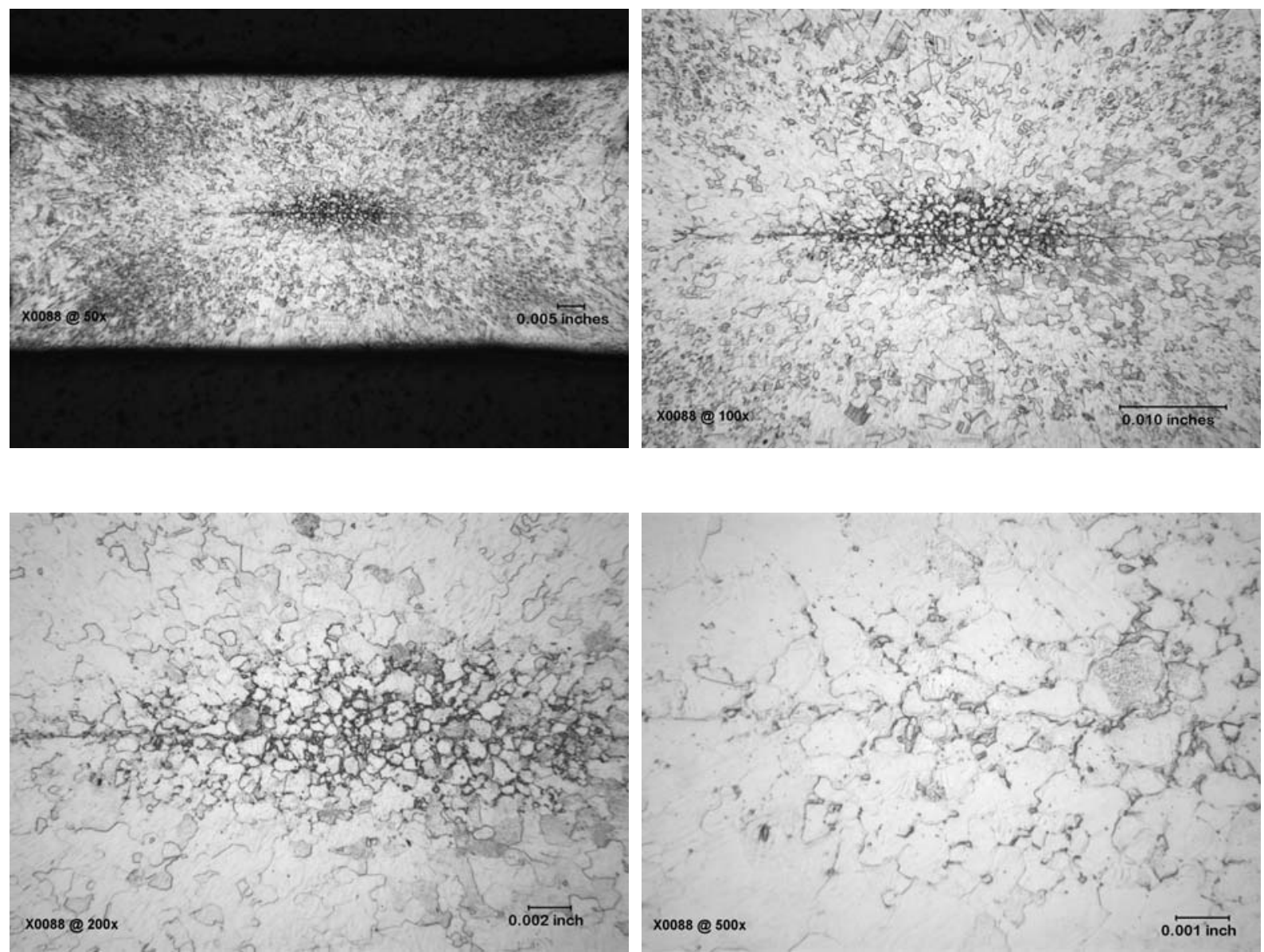

$x 0088 @ 500 x$

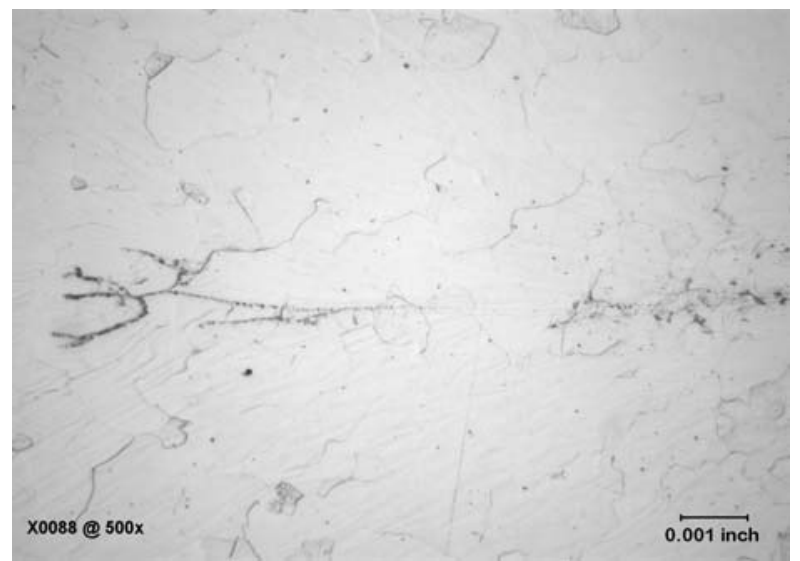

Figure A. 5 X0088, 3710 A, 12 Cycles, 1256 lbs, BR 2 
Rev. 1
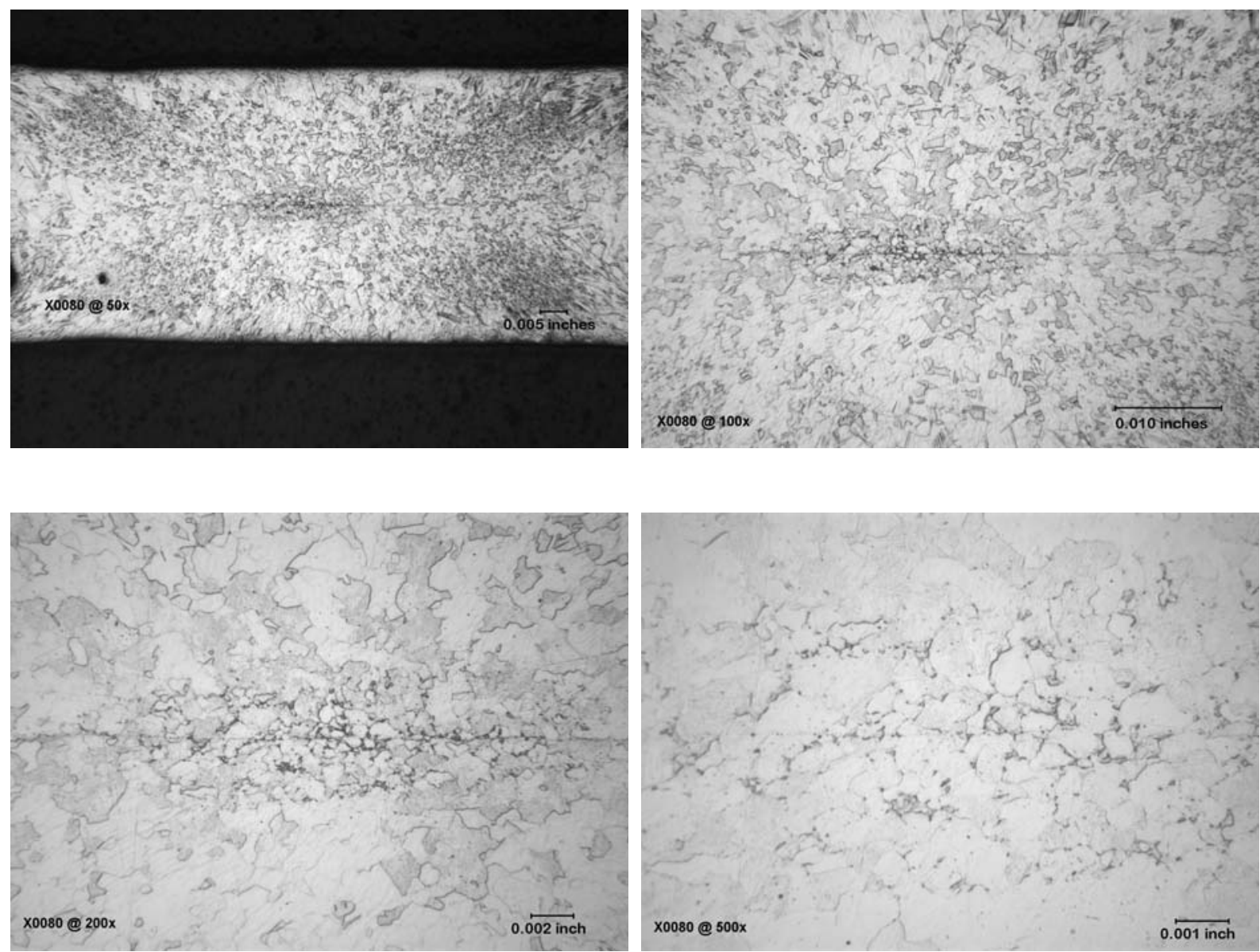

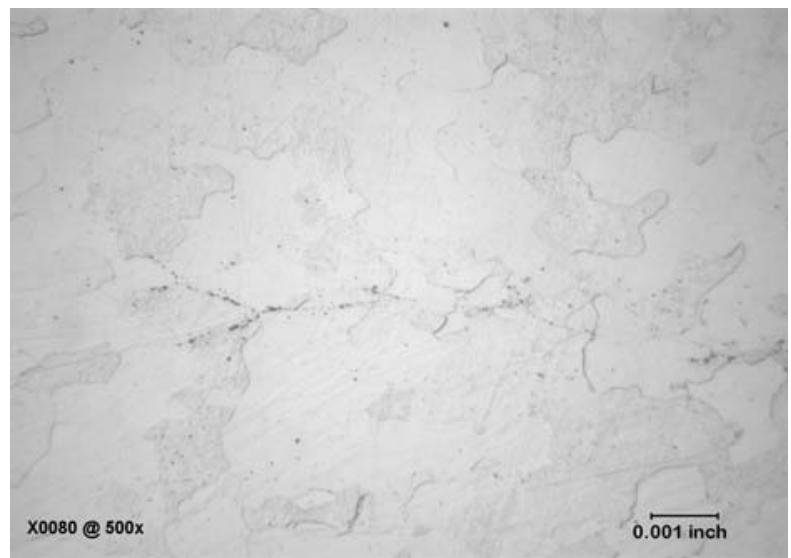

Figure A. 6 X0080, 3711 A, 12 Cycles, 1255 lbs, BR 2 
Rev. 1
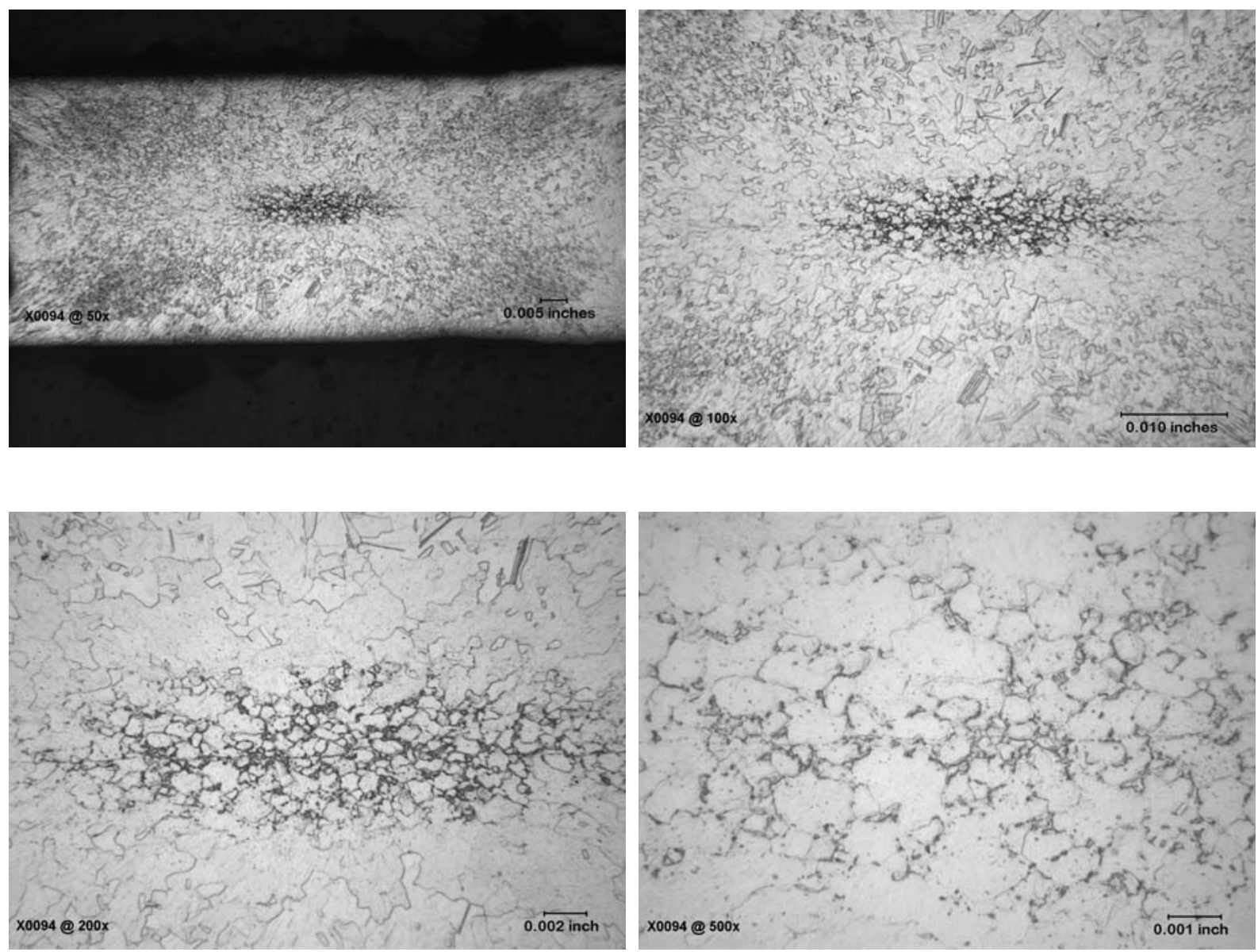

Figure A. 7 X0094, 3711 A, 12 Cycles, 1255 lbs, BR 2 
Rev. 1
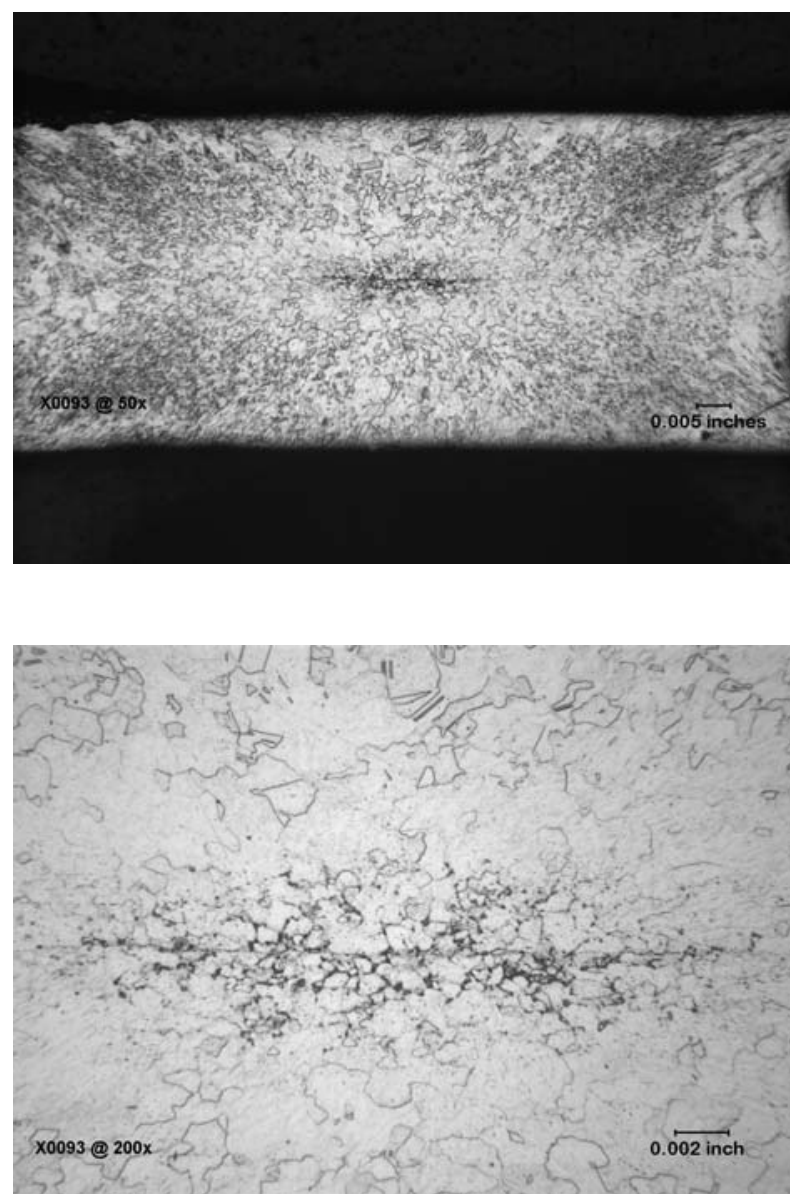
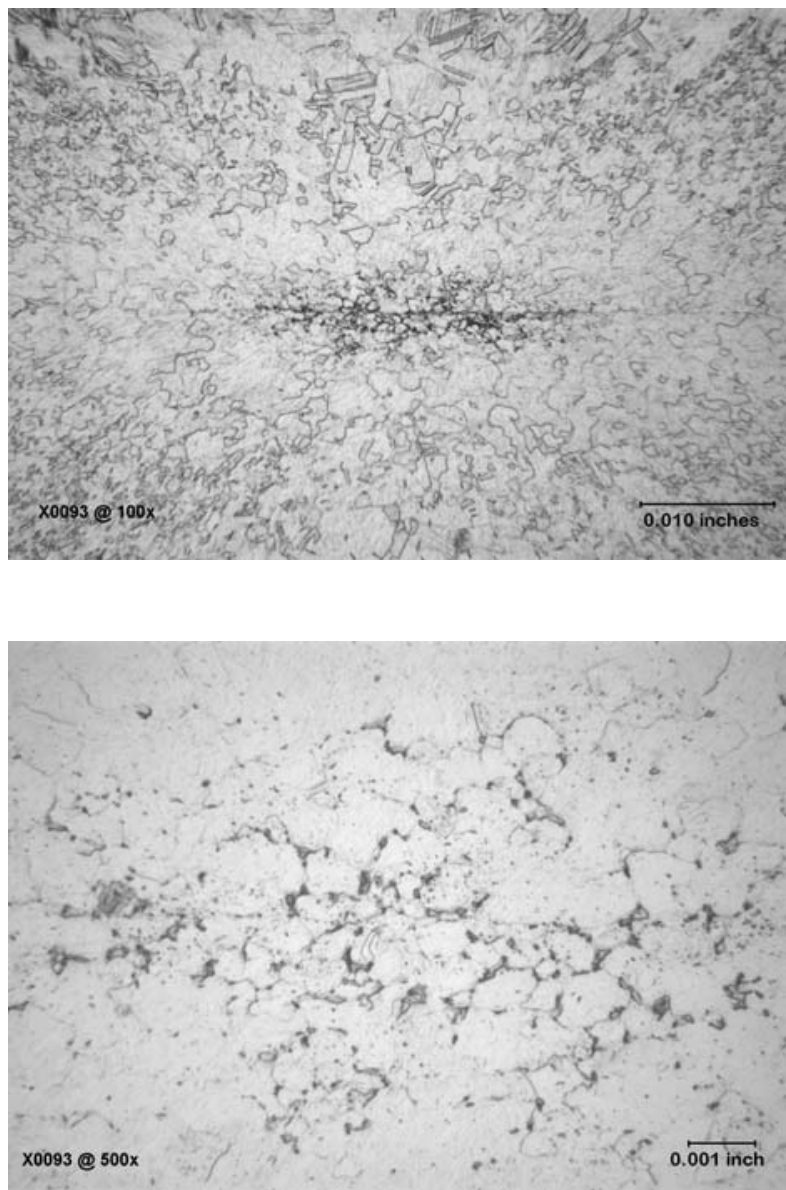

Figure A. 8 X0093, 3718 A, 13 Cycles, 1257 lbs, BR 2 
Rev. 1
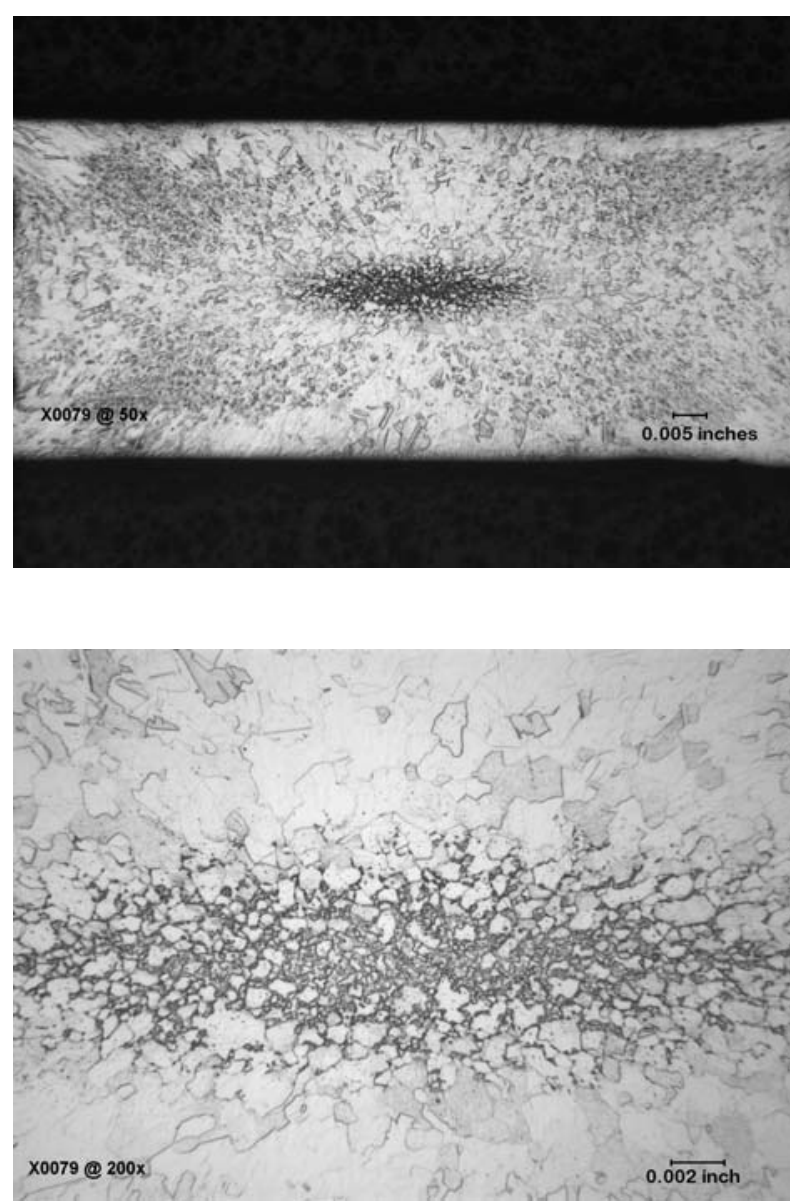
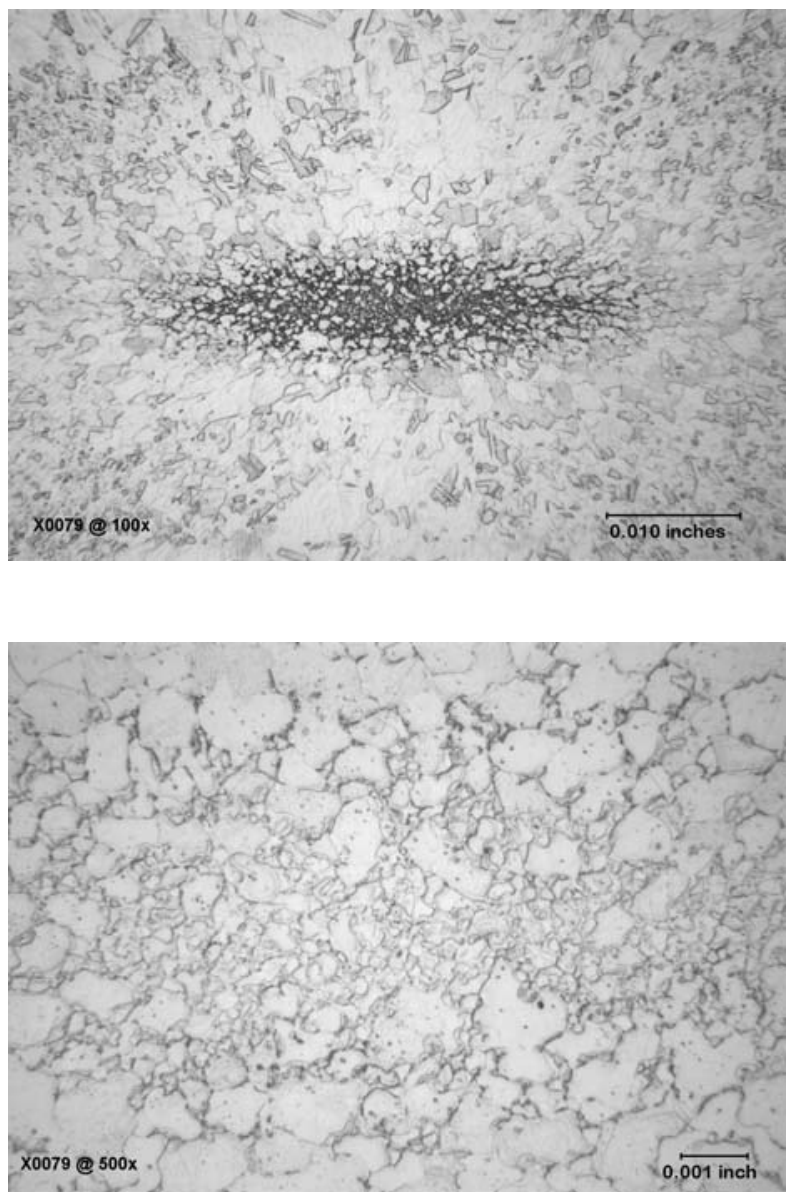

Figure A. 9 X0079, 3839 A, 11 Cycles, 1256 lbs, BR 1 
WSRC-STI-2006-00158 Optimization Study for Fill Stem

Page 25 of 32

Rev. 1

Manufacturing and Pinch Weld Processing
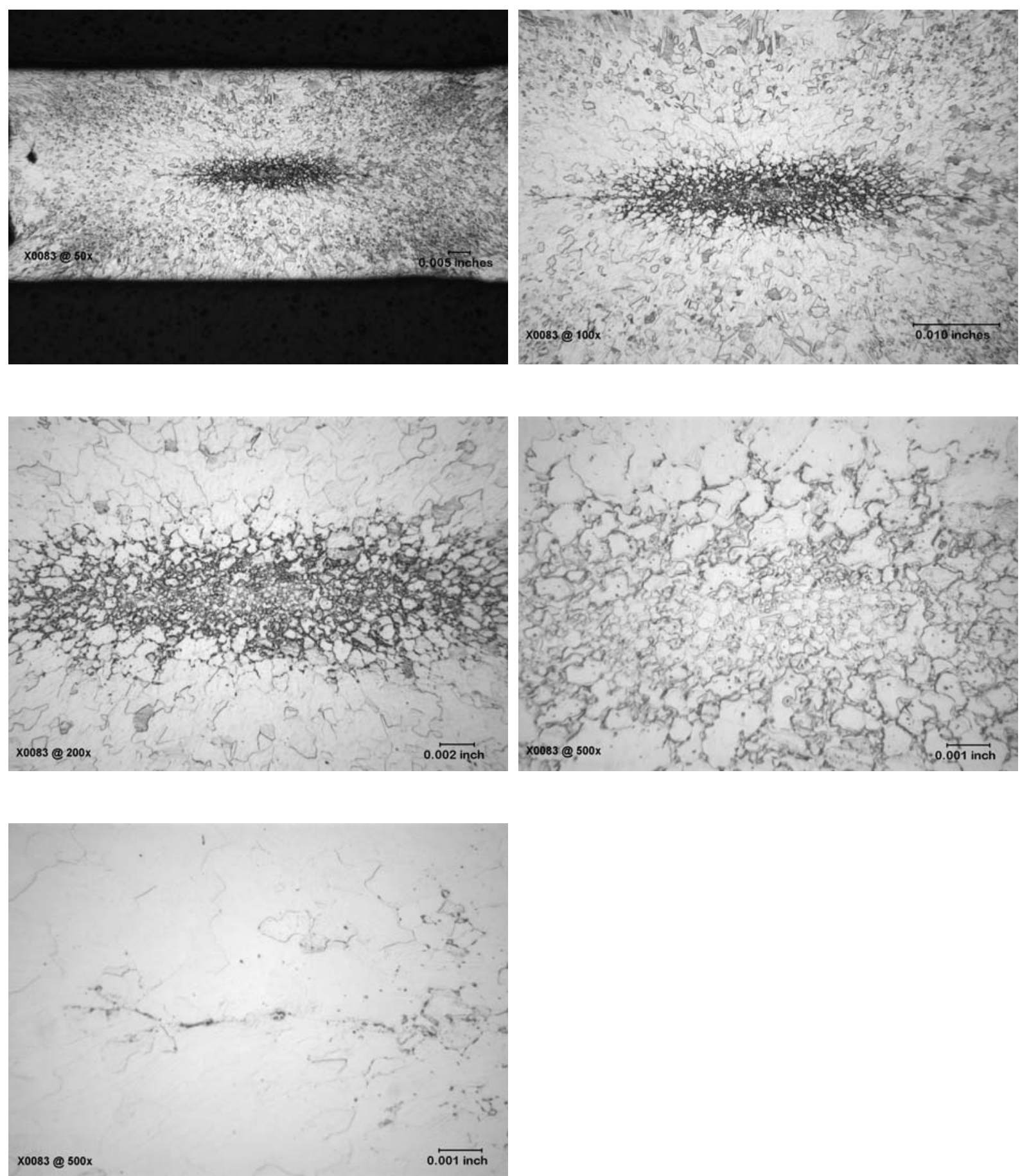

Figure A. 10 X0083, 3861 A, 13 Cycles, 1257 lbs, BR 1 
WSRC-STI-2006-00158 Optimization Study for Fill Stem

Page 26 of 32

Rev. 1

Manufacturing and Pinch Weld Processing
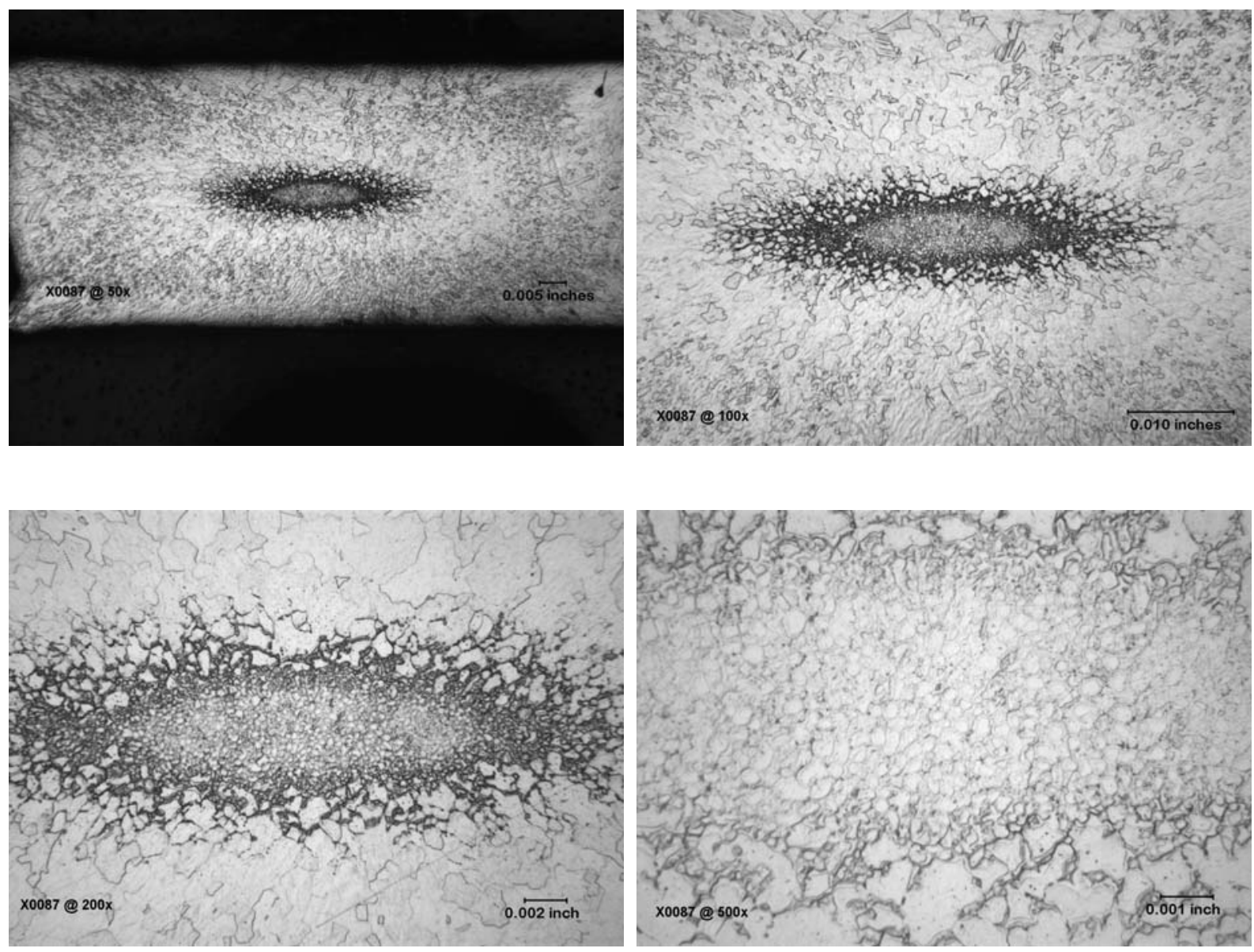

Figure A. 11 X0087, 3909 A, 12 Cycles, 1256 lbs, BR 1 


\section{Distribution}

D. Grote, H FM\&T

S. West, 773-A

N. Iyer, 773-41A

B. Davis, LANL

B. Meyer, LANL

M. Balmforth, SNL-CA

E Majzlik, SRNL, 773-A

E Clark, SRNL, 773-A

S Howard, SRNL, 730-A

B. West, DP, 235-H

M.E. DuPont 